\title{
Estimation and Projection of Petroleum Demand and Tax Collection from Petroleum Sector in India
}

No. 279

02-Sep-2019

Sacchidananda Mukherjee

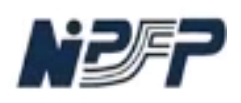

National Institute of Public Finance and Policy

New Delhi 


\title{
Estimation and Projection of Petroleum Demand and Tax Collection from Petroleum Sector in India
}

\author{
Sacchidananda Mukherjee* \\ *-Associate Professor, National Institute of Public Finance and Policy (NIPFP), 18/2, Satsang \\ Vihar Marg, Special Institutional Area, New Delhi - 110 067, INDIA. Fax: +91-11-26852548, \\ Mobile: +91-99539782879, E-mail: sachs.mse@gmail.com
}

\begin{abstract}
Revenue from taxes on petroleum products, crude petroleum and natural gas constitutes significant share in major indirect tax collection of the Union as well as State governments. The revenue share of petroleum taxes for the Union government has gone up whereas for the state governments it has gone down since 2010-11. Understanding revenue stream from petroleum taxes could help governments in better public finance management. The importance of revenue from petroleum sector has increased after the introduction of Goods and Services Tax (GST) in India, as fiscal autonomy of the governments (both federal as well as provincial) to augment tax collection through unilateral policy changes has been curtailed with harmonisation of the tax system. Revenue mobilisation from petroleum taxes is dependent on consumption (sales) of petroleum products and therefore understanding consumption of petroleum products is important to improve our understanding on revenue potential from petroleum sector. The objective of this paper is to estimate the petroleum consumption function (or demand function) and revenue (tax collection) function of petroleum sector for the period 2001-02 to 2016-17. Based on the estimated demand and revenue functions, we project the petroleum demand and tax collection from petroleum taxes for the period 2017-18 to 2024-25.
\end{abstract}

Key Words: petroleum products consumption; demand estimations; projections; petroleum taxes, revenue mobilisation, econometric models; India. 


\section{Introduction}

Revenue from taxes on petroleum products, crude petroleum and natural gas constitutes significant share in major indirect tax collection of the Union (federal) as well as State (provincial) governments. The Union government collects Union Excise Duties (UED) on petroleum products, cess on crude oil and Custom Duties (CD) on crude petroleum and petroleum products. State governments collect sales tax/ VAT, Central Sales Tax (CST), entry tax on crude petroleum, natural gas and petroleum products on states' landed price of these items. ${ }^{1}$ Table 1 shows that during 2010-17 on average 45 percent of Union taxes (from UED and CD) was collected from petroleum sector. During the same time, on average 26 percent of State taxes from Sales tax/ VAT (including Central Sales Tax and Entry Tax) was collected from petroleum sector. The revenue share of petroleum taxes for the Union government has gone up whereas for the state governments it has gone down since 2010-11.

Table 1: Collection of Union and State Taxes from Petroleum Sector

\begin{tabular}{crrrrrr}
\hline Year & $\begin{array}{c}\text { Union Taxes from } \\
\text { Petroleum Sector } \\
\text { (Rs. Crore) }\end{array}$ & $\begin{array}{c}\text { State Taxes from } \\
\text { Petroleum Sector } \\
\text { (Rs. Crore) }\end{array}$ & $\begin{array}{c}\text { Union Taxes } \\
\text { from Customs } \\
\text { \& Union } \\
\text { Excise Duties* } \\
\text { (Rs. Crore) }\end{array}$ & $\begin{array}{c}\text { States Taxes } \\
\text { from Sales } \\
\text { Tax/VAT, CST \& } \\
\text { Entry Tax } \\
\text { (Rs. Crore) }\end{array}$ \\
\hline $\mathbf{2 0 0 5 - 0 6}$ & 63,143 & $(46.9)$ & 45,934 & $(34.5)$ & 134,533 & 133,103 \\
\hline $\mathbf{2 0 1 0 - 1 1}$ & 102,828 & $(49.2)$ & 80,709 & $(28.0)$ & 209,167 & 288,624 \\
\hline $\mathbf{2 0 1 1 - 1 2}$ & 95,229 & $(40.1)$ & 100,375 & $(28.2)$ & 237,433 & 355,340 \\
\hline $\mathbf{2 0 1 2}-13$ & 98,603 & $(35.4)$ & 111,438 & $(26.7)$ & 278,691 & 417,613 \\
\hline $\mathbf{2 0 1 3 - 1 4}$ & 104,163 & $(38.0)$ & 127,957 & $(27.2)$ & 274,078 & 471,055 \\
\hline $\mathbf{2 0 1 4 - 1 5}$ & 122,925 & $(39.2)$ & 131,599 & $(25.7)$ & 313,216 & 511,870 \\
\hline $\mathbf{2 0 1 5}-16$ & 213,995 & $(57.4)$ & 129,214 & $(23.5)$ & 372,799 & 549,427 \\
\hline $\mathbf{2 0 1 6}-17$ & 237,388 & $(52.6)$ & 153,287 & $(25.1)$ & 451,380 & 611,159 \\
\hline
\end{tabular}

Note: Figures in the parenthesis show the percentage share in respective taxes of the governments.

*-Net of States' share but includes Sales tax collection from UTs (including Delhi \& Puducherry)

On average petroleum taxes contribute 2.7 percent of GDP during 2001-17 where the average share of union taxes is 56 percent and that of the state taxes is 44 percent. Figure 1 presents the trends in petroleum tax collection (as \% of GDP) during 2001-17. It shows that during 2008-15, average petroleum tax collection (as \% of GDP) has gone down as compared to 2002-08. The difference in average share during 2002-08 to 2008-15 is 0.86 percent of GDP. The fall in revenue collection from petroleum taxes during 2008-15 is mostly attributed to cut in UED on petroleum products, announced as a part of fiscal stimulus package to moderate the impact of global financial crisis. Aftermath of the crisis, persistently high

\footnotetext{
${ }^{1}$ In addition the Union Government collects Corporate Income Tax and Service Tax from petroleum companies, royalties on offshore exploration of crude petroleum and natural gas. State governments collect royalties on onshore exploration of crude oil and natural gas. CIT, Service Tax and royalties (resource rent) are not included in the present study.
} 
international crude oil price (during 2011-14) and growing exchange rate of Indian rupee vis-à-vis USD, left no room for the union government to increase the UED on petroleum products during 2008-15. However, gradual fall in international crude oil prices since July 2014 enabled the government to increase excise duties on petroleum products which resulted in higher tax collection since 2015-16. The imposition of higher excise duties on petroleum products arrested the fall in domestic prices of petroleum products. In other words, the benefit of lower international crude oil price did not passed on to the consumers in terms of lower prices of petroleum products in the domestic market. The benefits of increasing UED on petroleum products did not result in equal benefits to states' tax collection. Perhaps landed price of petroleum products for states was high and left no room for the state governments to increase state taxes (sales tax / VAT) on petroleum products to augment revenue collection from petroleum products. Given the political costs associated with increasing prices of petroleum products, states have avoided to increase sales tax / VAT on petroleum products, as a result state tax collection from petroleum sector do not show rising trend during 2015-17 as visible for the union taxes.

Figure 1: Collection of Petroleum Taxes (as Percentage of GDP)

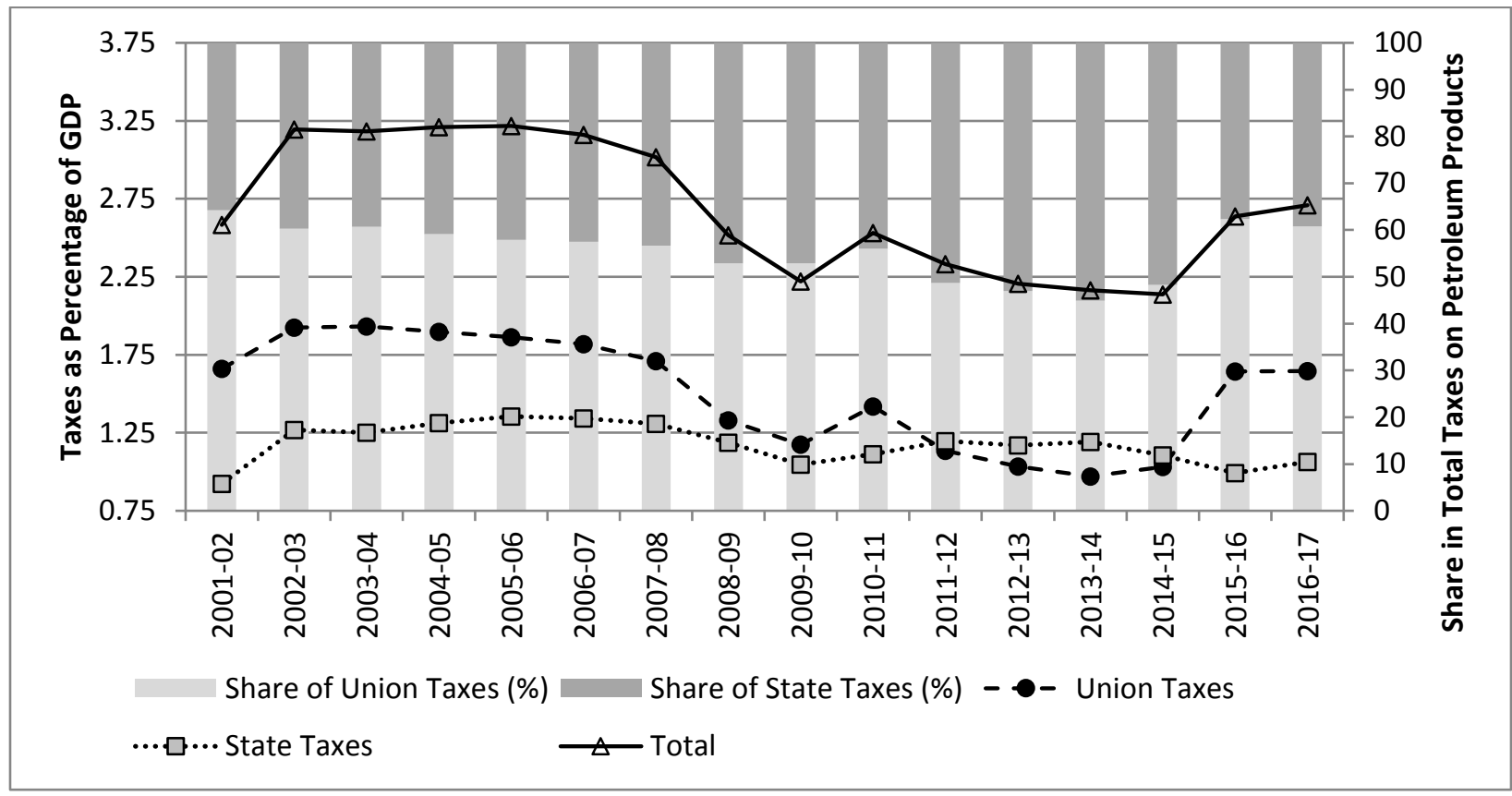

Source: Compiled from various issues of Indian Petroleum and Natural Gas Statistics (MoP\&NG 200910 to 2017-18) and EPWRF India Time Series Database.

Petroleum sector faces a special tax treatment as compared to other sectors and there are two major drivers for petroleum taxation. Given the environmental impacts associated with combustion of petroleum products, mainly in terms of air pollution potential of consumption of fossil fuels, it is categorised as sin good (as per with intoxicants like tobacco, tobacco products and alcoholic beverages). Therefore, higher tax on petroleum products is often supported by environmentalists and citizens having concern for environment and public health. Given the environmental detrimental impacts of combustion of transport fuels 
and costs associated with mortality and morbidity of urban air pollution, petroleum products attract higher tax rates as compared to other goods and services. Secondly, being necessary inputs for transportation/ mobility, demand for petroleum products is relatively price inelastic. Therefore, according to the theory of optimal taxation petroleum products attract higher tax rate, as it is expected that incidence of petroleum taxation would rest upon consumers and therefore it would be less distortionary. In addition, there is an additional factor specific to Indian petroleum sector which induce higher taxation for petroleum sector. Indian petroleum sector is dominated by Central Public Sector Undertakings (CPSUs) with limited number of market participants in refining of crude oil as well as distribution of refinery products. Moreover administered pricing mechanism used to prevail earlier did not allow full price pass through for some refinery products (domestic / non-commercial liquefied petroleum gas, public distribution system kerosene, diesel and petrol) and also denied compensation (subsidies) to private players for any loss on account of under recoveries from sales of these items. Being under CPSUs with limited number of market operators, petroleum sector is always a 'easy- to-tax' sector for both the Union and State tax administrators. ${ }^{2}$ There is also expectation that revenue leakage from the petroleum sector would be minimal given the involvement of CPSUs. The special tax treatment of the petroleum sector has also denied Input Tax Credit (ITC) against tax liability for majority of high value petroleum products like petrol, diesel and ATF. In addition to the three petroleum products, crude petroleum and natural gas used to be kept out of the Central Value Added Tax (CenVAT) as well as State VAT system (Mukherjee and Rao 2015). Though these items are kept under the Goods and Services Tax (GST), actual implementation of GST for these items is yet to be decided by the GST Council (Mukherjee and Rao 2019). Apart from the three petroleum products (petrol, diesel and ATF) all other petroleum products attract GST.

Understanding demand for petroleum products is important to improve our understanding on revenue potential from petroleum sector. Estimation of demand function for petroleum sector in a simple way without compromising on scientific rigour could help both Union and State governments to make estimation of prospective tax revenue from petroleum sector. The issue of understanding revenue stream from petroleum sector could help governments in their public finance management. Revenue importance of the petroleum sector has heightened after the introduction of Goods and Services Tax (GST) in India from 1 July 2017. Introduction of GST has curtailed fiscal autonomy of both the federal as well as provincial governments. In other words, in the face of additional revenue requirement (demand) neither the Union nor State governments could deviate from common harmonised tax system (structure) designed under the GST unilaterally. Every decision on GST needs to be backed by broad consensus in the GST Council (Mukherjee 2015). Unlike the Union government, State governments have limited taxation power (tax handles) to cope up with any revenue shortfall on account of GST collection. ${ }^{3}$ Moreover, GST subsumes a substantial part of own tax revenue of States and left with limited fiscal autonomy to augment revenue from elsewhere to compensate any substantial revenue shortfall on account of GST collection (Mukherjee 2019a). Though the Union government has agreed to compensate states for any shortfall in State GST (SGST) collection from the projected GST collection during the first five years of GST introduction, ${ }^{4}$ any shortfall in Central GST (CGST) collection will spill over to

\footnotetext{
${ }^{2}$ It is a common belief that tax compliance of public sector units is higher than private entities.

${ }^{3}$ Given shortfall in GST collection, the Union Government has increased tax rates on diesel and petrol in the Union Budget 2019-20.

4 The projection of GST revenue is based on annual growth rate of 14 percent with reference to net collection of taxes subsumed under GST in 2015-16.
} 
The present study would be useful for policy as future demands for petroleum products will generate demands for import of crude petroleum, investments in petroleum reserve; refining capacity; associated sectors like petroleum transportation (e.g., pipeline) and distribution infrastructure, other chemicals and inputs required in petroleum refineries and manpower/ skill development. Projection of petroleum taxes forms an inseparable part of budgeting exercise for governments in many countries. ${ }^{5}$ It is expected that the present study could help both the Union and State governments in India to project petroleum tax collection in their budgeting exercise.

In the next section we describe methodology of our study and available data to estimate the models. We also estimate our models in section 2 . In section 3 , we project petroleum demands and tax collection from petroleum sector. Based on our analysis, we draw our conclusions in section 4 .

\section{Methodology and Data Sources}

In literature, there are broadly two types of studies available for projection of petroleum revenue for a country or state. The first category of studies project revenue from petroleum sector for oil producing countries where the main objective is to estimate future investment demands based on projection of expected revenue from crude petroleum production. Moreover these studies are related to revenues from sales and rents (royalties) of crude petroleum rather than on tax revenue. Unlike tax revenue, revenue from sales of crude petroleum depends on expected global aggregate production of crude petroleum, expected world's demands and prices of crude oil (e.g., Daniel undated, Stephens 2019). The second category studies are related to estimation of petroleum demand function and projection of associated tax revenue thereof (e.g., Berwick and Malchose 2012, Sunley et al. 2002).

So far India specific studies have mostly focused on estimation of demand function of petroleum sector and projections future demands based on time series modelling (e.g., Agrawal 2012, Parikh et al. 2007). As per our information, there is no study in India which estimates tax revenue function for petroleum sector based on demand function of petroleum and therefore the present study fills the gap.

In this paper we estimate three types of models / estimations based on alternative frequency (annual and quarterly data) and granularity (general government vs. state government) of the data available for the petroleum sector.

\footnotetext{
${ }^{5}$ For example, Office for Budget Responsibility (OBR) conducts forecast of UK oil and gas revenues for HM Revenue and Customs for each fiscal event (https://obr.uk/forecasts-in-depth/tax-by-tax-spend-byspend/oil-and-gas-revenues/). The Department of Revenue, the Department of Natural Resources (DNR), the Alaska Permanent Fund Corporation, and the Office of Management and Budget together conduct projections for petroleum and non-petroleum revenue for the Tax Division of Alaska Department of Revenue (http://www.tax.alaska.gov/programs/documentviewer/viewer.aspx?1531r).
} 


\subsection{Models Based on Annual Data}

Available annual data specific to demand (consumption), prices, availability and collection of union and state taxes from petroleum sector are presented in Table 3 and 4 . Though product-wise consumption of petroleum products is available from the online database of Petroleum Policy Analysis Cell (PPAC), we have taken aggregate consumption as our objective is to estimate overall demand for petroleum products and revenue (tax collection) thereof. Based on annual data presented in Table 3 and Table 4, we have estimated demand function and revenue function for petroleum products in this section. It is to be mentioned that price of natural gas is still administered in India and this makes it difficult to project the future price of natural gas. Unlike petroleum products, natural gas consumption in India is constrained by availability (supply). Given the uncertainties associated with prospective domestic production and imports of natural gas, it is difficult to project the future availability of natural gas in India.

Table 3: Annual Data on Collection of Petroleum Taxes (Rs. Crore)

\begin{tabular}{|c|c|c|c|c|c|c|c|c|}
\hline Year & $\begin{array}{l}\text { Union } \\
\text { Taxes }\end{array}$ & $\begin{array}{c}\text { Central } \\
\text { Excise } \\
\text { Duty }\end{array}$ & $\begin{array}{c}\text { Customs } \\
\text { Duty }\end{array}$ & $\begin{array}{l}\text { State } \\
\text { Taxes } \\
\text { on } \\
\text { Crude } \\
\text { Oil }\end{array}$ & $\begin{array}{c}\text { State } \\
\text { Taxes } \\
\text { on } \\
\text { Natural } \\
\text { Gas }\end{array}$ & $\begin{array}{c}\text { State Taxes } \\
\text { on } \\
\text { Petroleum } \\
\text { Products }\end{array}$ & $\begin{array}{l}\text { Total } \\
\text { State } \\
\text { Taxes }\end{array}$ & $\begin{array}{c}\text { Total Taxes } \\
\quad \text { on } \\
\text { Petroleum } \\
\text { Sector (tax) }\end{array}$ \\
\hline (1) & $\begin{array}{c}(2) \\
(3+4)\end{array}$ & (3) & (4) & (5) & (6) & (7) & $\begin{array}{c}(8) \\
(5+6+7)\end{array}$ & $(9)(2+8)$ \\
\hline 2001-02 & 36,104 & 29,337 & 6,767 & 533 & 852 & 18,705 & 20,090 & 56,194 \\
\hline 2002-03 & 45,127 & 35,961 & 9,166 & 993 & 844 & 27,903 & 29,741 & 74,868 \\
\hline 2003-04 & 50,733 & 40,151 & 10,582 & 875 & 913 & 31,061 & 32,849 & 83,582 \\
\hline 2004-05 & 56,395 & 43,145 & 13,250 & 1,270 & 854 & 36,877 & 39,000 & 95,395 \\
\hline 2005-06 & 63,143 & 51,749 & 11,394 & 1,187 & 1,078 & 43,669 & 45,934 & 109,077 \\
\hline 2006-07 & 71,893 & 57,884 & 14,009 & 1,535 & 1,485 & 50,066 & 53,086 & 124,979 \\
\hline 2007-08 & 78,373 & 60,231 & 18,142 & 1,656 & 1,451 & 56,784 & 59,890 & 138,263 \\
\hline 2008-09 & 70,557 & 59,383 & 11,174 & 1,301 & 2,235 & 59,426 & 62,962 & 133,519 \\
\hline 2009-10 & 71,767 & 64,012 & 7,755 & 1,608 & 2,703 & 59,637 & 63,949 & 135,716 \\
\hline 2010-11 & 102,828 & 76,546 & 26,282 & 1,499 & 3,998 & 75,212 & 80,709 & 183,537 \\
\hline 2011-12 & 95,229 & 74,710 & 20,519 & 1,916 & 4,728 & 93,732 & 100,375 & 195,604 \\
\hline 2012-13 & 98,603 & 84,898 & 13,705 & 1,760 & 5,558 & 104,121 & 111,438 & 210,041 \\
\hline 2013-14 & 104,163 & 88,600 & 15,563 & 1,662 & 5,604 & 120,692 & 127,957 & 232,120 \\
\hline 2014-15 & 122,925 & 110,353 & 12,572 & 1,938 & 5,987 & 123,675 & 131,599 & 254,524 \\
\hline 2015-16 & 213,995 & 198,793 & 15,202 & 2,018 & 5,303 & 121,893 & 129,214 & 343,209 \\
\hline 2016-17 & 237,388 & 229,143 & 8,245 & 2,213 & 4,278 & 146,796 & 153,287 & 390,675 \\
\hline
\end{tabular}

Source: Compiled from various issues of Indian Petroleum and Natural Gas Statistics (MoP\&NG 2010 to 2018) 
Table 4: Annual Data on Consumption, Availability and Prices of Crude Petroleum, Natural Gas and Petroleum Products

\begin{tabular}{|c|c|c|c|c|c|c|}
\hline Year & $\begin{array}{c}\text { Average } \\
\text { Annual } \\
\text { Crude Oil } \\
\text { Price } \\
\text { (Indian } \\
\text { Basket) } \\
\text { (USD/bbl) } \\
\text { (crudepr) }\end{array}$ & $\begin{array}{c}\text { Total } \\
\text { Consumption } \\
\text { of Natural } \\
\text { Gas (in } \\
\text { MMSCM)* } \\
\text { (conng) }\end{array}$ & $\begin{array}{l}\text { Consumer } \\
\text { Price of } \\
\text { Natural } \\
\text { Gas (Rs. } \\
\text { Per } \\
\text { Thousand } \\
\text { cubic } \\
\text { metre)** } \\
\text { (ngprice) }\end{array}$ & $\begin{array}{c}\text { Net } \\
\text { Availability } \\
\text { of Natural } \\
\text { Gas (in } \\
\text { MMSCM) } \\
\text { (availng) }\end{array}$ & $\begin{array}{l}\text { Consumption } \\
\text { of Petroleum } \\
\text { Products } \\
\text { ('000 tonne) } \\
\text { (polcon) }\end{array}$ & $\begin{array}{c}\text { GDP at } \\
\text { factor cost } \\
\text { (current } \\
\text { prices, Rs. } \\
\text { Crore) } \\
\text { (2004-05 } \\
\text { series) } \\
(g d p)\end{array}$ \\
\hline (1) & (10) & (11) & (12) & (13) & (14) & (15) \\
\hline 2001-02 & 22.55 & 28,037 & 2,850 & 28,026 & 100,432 & $2,175,260$ \\
\hline 2002-03 & 26.60 & 29,964 & 2,850 & 29,964 & 104,126 & $2,343,864$ \\
\hline 2003-04 & 27.98 & 30,906 & 2,850 & 30,906 & 107,751 & $2,625,819$ \\
\hline 2004-05 & 39.21 & 30,775 & 2,850 & 30,775 & 111,634 & $2,971,464$ \\
\hline 2005-06 & 55.72 & 31,025 & 2,850 & 31,326 & 113,213 & $3,390,503$ \\
\hline 2006-07 & 62.46 & 31,368 & 3,200 & 30,792 & 120,749 & $3,953,276$ \\
\hline 2007-08 & 79.25 & 30,579 & 3,200 & 31,479 & 128,946 & $4,582,086$ \\
\hline 2008-09 & 83.57 & 34,524 & 3,200 & 31,746 & 133,599 & $5,303,567$ \\
\hline 2009-10 & 69.76 & 48,344 & 3,200 & 46,521 & 137,808 & $6,108,903$ \\
\hline 2010-11 & 85.09 & 52,019 & 3,200 & 51,251 & 141,040 & $7,248,860$ \\
\hline 2011-12 & 111.89 & 60,684 & 7,499 & 46,481 & 148,132 & $8,106,946$ \\
\hline 2012-13 & 107.97 & 53,915 & 8,387 & 39,777 & 157,057 & $8,890,428$ \\
\hline 2013-14 & 105.52 & 48,994 & 9,067 & 34,638 & 158,407 & $10,011,513$ \\
\hline 2014-15 & 84.16 & 46,955 & 10,168 & 32,792 & 165,520 & $11,113,918$ \\
\hline 2015-16 & 46.17 & 47,850 & 11,548 & 31,243 & 184,674 & $12,147,824$ \\
\hline 2016-17 & 47.56 & 50,778 & 8,138 & 31,731 & 194,597 & $13,463,047$ \\
\hline
\end{tabular}

Notes: *- MMSCM is abbreviation of 'Million Metric Standard Cubic Meters'

**- as on 1 April / at the beginning of a year, Off-shore (Landfall point) and On Shore.

Source: Compiled from various issues of Indian Petroleum and Natural Gas Statistics 2009-10 to 201718 (MoP\&NG 2010 to 2018), Petroleum Policy Analysis Cell (PPAC) Online Database and EPWRF India Time Series Database

To understand the trend in tax collection from petroleum sector, we present the total tax collection (corresponding to Column 9 of Table 3 ) from the petroleum sector in Figure 2. It shows that there are two breaks in the trend of total tax collection during 2001-17. The first break occurred in 2008-09 and tax collection was stagnant during 2008-10. Stagnation in collection of petroleum taxes during 2008-10 is associated with fall in annual growth rate in UED collection in 2008-09 as well as stagnation in annual growth rate in sales of petroleum products during 2008-11. To capture this break we introduced dum0809 in our estimations. Thereafter a second break is observed from 2014-15 where tax collection accelerates. The reason behind such increase in tax collection is related to sharp fall in price of crude oil (Indian basket) in 2014-15 which induced the Union government to raise UED on petroleum 
products. Though the move of increasing UED on petroleum products arrested the fall in domestic prices of petroleum products, annual growth rate of consumption of petroleum products increased from 0.9 percent in 2013-14 to 4.5 percent in 2014-15 and 11.6 percent in 2015-16 which resulted in higher tax collection. To capture this break, we have introduced dum1415 in our estimations.

Figure 2: Total Tax Collection from Petroleum Sector (Rs. Crore)

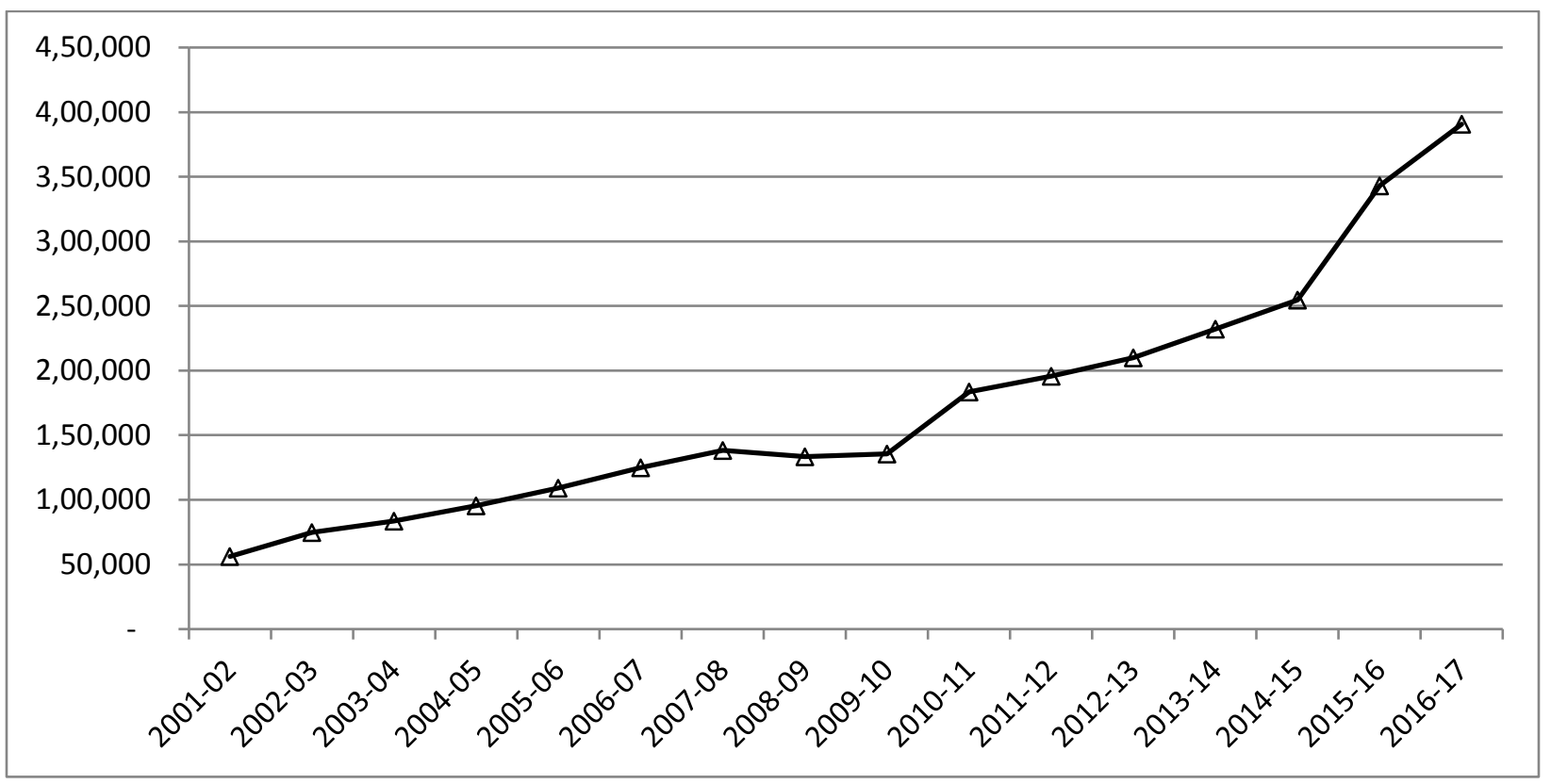

Source: Computed

We have used the following functional relationships (equations) equations to understand the factors influencing consumption / sales of petroleum products and the relationship between sales of petroleum products and tax revenue.

Consumption of Petroleum Products $=f(G D P$, Price of Crude Oil - Indian Basket, $X)$

Total Tax Collection from Petroleum Sector $=f($ Consumption of Petroleum Products, $X)(2)$

Where, $\mathrm{X}$ is some policy related variables/ dummies.

The underlying data for estimation of the equations are presented in Table $3 \& 4$. All variables are taken in their logarithm form and list of variables are presented below:

Ipolcon: Log of consumption (sales) of petroleum products (in '000 tonne) (also mentioned as Isales)

Igdp: Log of Gross Domestic Product (at factor cost, current prices, 2004-05 series) (in Rs. Crore) 
$\operatorname{lgdp^{2}}=$ Square of log of Gross Domestic Product (at factor cost, current prices, 2004-05 series) (in Rs. Crore)

lcrudepr: Log of Price of Crude Oil (Indian Basket) (in USD per billion barrel, bbl) (also mentioned as lcrudperice)

Itax: Log of total tax collection from petroleum sector (in Rs. Crore)

dum0809: 1 for the year 2008-09 and 2009-10 and 0 otherwise

dum1415: 1 for years from 2014-15, 0 otherwise

However, it is to be mentioned here that revenue from petroleum taxes does not depend only on consumption of petroleum products but also on consumption of crude petroleum and natural gas. Though consumption of crude petroleum will be captured through consumption of petroleum products (crude petroleum imbedded in petroleum products and there are no alternative uses of crude petroleum without refining), we need to capture consumption of natural gas separately to get the complete consumption profile of the petroleum sector. Therefore, we present the following two additional equations:

Consumption of Natural Gas = f(GDP, Price of Natural Gas, Availability of Natural Gas, X)

Total Tax Collection from Petroleum Sector $=f($ Consumption of Petroleum Products, Consumption of Natural Gas, $X$ )

The list of variables for second set of models is presented as follows:

lconng: Log of Consumption of Natural Gas (in MMSCM)

Ingprice: Log of Price of Natural Gas (in Rs. per thousand cubic metre)

lavailng: Log of Net Availability of Natural Gas (in MMSCM)

Since the data used in our analysis may contain some time series properties (especially presence of unit root), we have carried out the following time series tests.

\section{Unit Root Test}

We have conducted Augmented Dickey-Fuller (ADF) and Phillips-Perron (PP) tests to test whether the series are stationary. We have presented the test results in Table 5 and it shows that all series are stationery at their first difference (i.e., integrated of order 1 or I(1)). 
Table 5: Results of Unit Root Tests - Annual Data

\begin{tabular}{|c|c|c|c|c|c|c|c|c|c|}
\hline \multirow{3}{*}{ Variable } & \multirow{3}{*}{ Specification } & \multicolumn{4}{|c|}{ Level } & \multicolumn{4}{|c|}{ First Difference } \\
\hline & & \multicolumn{2}{|c|}{$\begin{array}{l}\text { Augmented } \\
\text { Dickey-Fuller } \\
\text { test statistic }\end{array}$} & \multicolumn{2}{|c|}{$\begin{array}{l}\text { Phillips-Perron } \\
\text { test statistic }\end{array}$} & \multicolumn{2}{|c|}{$\begin{array}{l}\text { Augmented } \\
\text { Dickey-Fuller } \\
\text { test statistic }\end{array}$} & \multicolumn{2}{|c|}{$\begin{array}{l}\text { Phillips-Perron } \\
\text { test statistic }\end{array}$} \\
\hline & & Statistic & $\begin{array}{c}\text { p- } \\
\text { value }\end{array}$ & Statistic & $\begin{array}{c}\mathrm{p}- \\
\text { value }\end{array}$ & Statistic & $\begin{array}{c}\text { p- } \\
\text { value }\end{array}$ & Statistic & $\begin{array}{c}\text { p- } \\
\text { value }\end{array}$ \\
\hline \multirow[t]{3}{*}{$\operatorname{ltax}$} & None & 5.03 & 1.00 & 6.20 & 1.00 & -2.23 & 0.03 & -2.20 & 0.03 \\
\hline & Intercept & -0.42 & 0.88 & -0.36 & 0.89 & -4.11 & 0.01 & -4.47 & 0.00 \\
\hline & $\begin{array}{l}\text { Trend \& } \\
\text { Intercept }\end{array}$ & -2.52 & 0.31 & -2.63 & 0.27 & -4.02 & 0.03 & -6.08 & 0.00 \\
\hline \multirow[t]{3}{*}{ lpolcon } & None & 4.31 & 1.00 & 10.51 & 1.00 & 0.29 & 0.75 & -1.19 & 0.20 \\
\hline & Intercept & 1.27 & 1.00 & 3.84 & 1.00 & -4.25 & 0.01 & -3.50 & 0.02 \\
\hline & $\begin{array}{l}\text { Trend \& } \\
\text { Intercept }\end{array}$ & -3.14 & 0.14 & -0.91 & 0.93 & -4.61 & 0.02 & -5.19 & 0.01 \\
\hline \multirow[t]{3}{*}{ lcrudepr } & None & 0.54 & 0.82 & 0.42 & 0.79 & -2.44 & 0.02 & -2.40 & 0.02 \\
\hline & Intercept & -2.02 & 0.27 & -2.01 & 0.28 & -2.38 & 0.16 & -2.34 & 0.17 \\
\hline & $\begin{array}{l}\text { Trend \& } \\
\text { Intercept }\end{array}$ & -0.19 & 0.99 & 0.88 & 1.00 & -8.55 & 0.00 & -3.87 & 0.04 \\
\hline \multirow[t]{3}{*}{ lgdp } & None & 1.97 & 0.98 & 12.11 & 1.00 & -0.14 & 0.62 & -0.08 & 0.64 \\
\hline & Intercept & -0.75 & 0.80 & -0.63 & 0.84 & -2.39 & 0.16 & -2.39 & 0.16 \\
\hline & $\begin{array}{l}\text { Trend \& } \\
\text { Intercept }\end{array}$ & -1.53 & 0.76 & -1.16 & 0.88 & -2.94 & 0.18 & -5.16 & 0.01 \\
\hline \multirow[t]{3}{*}{ lconng } & None & 1.37 & 0.95 & 1.19 & 0.93 & -2.41 & 0.02 & -2.40 & 0.02 \\
\hline & Intercept & -1.05 & 0.71 & -1.13 & 0.68 & -2.51 & 0.13 & -2.51 & 0.13 \\
\hline & $\begin{array}{l}\text { Trend \& } \\
\text { Intercept }\end{array}$ & -1.30 & 0.85 & -1.56 & 0.76 & -2.40 & 0.36 & -2.41 & 0.36 \\
\hline \multirow[t]{3}{*}{ lngprice } & None & 1.06 & 0.92 & 1.07 & 0.92 & -3.01 & 0.01 & -3.01 & 0.01 \\
\hline & Intercept & -0.69 & 0.82 & -0.69 & 0.82 & -3.16 & 0.04 & -3.16 & 0.05 \\
\hline & $\begin{array}{l}\text { Trend \& } \\
\text { Intercept }\end{array}$ & -1.98 & 0.57 & -1.98 & 0.57 & -2.90 & 0.19 & -2.89 & 0.19 \\
\hline \multirow[t]{3}{*}{ lavailng } & None & 0.23 & 0.74 & 0.19 & 0.73 & -2.51 & 0.02 & -2.55 & 0.02 \\
\hline & Intercept & -2.10 & 0.25 & -1.70 & 0.41 & -2.41 & 0.16 & -2.45 & 0.15 \\
\hline & $\begin{array}{l}\text { Trend \& } \\
\text { Intercept }\end{array}$ & -2.01 & 0.55 & -1.36 & 0.83 & -2.39 & 0.37 & -2.44 & 0.35 \\
\hline
\end{tabular}

Source: Estimated

\section{Cointegration Test}

Johansen Cointegration Test is conducted to see if there is any long-run relationship among variables selected in our estimations. We have conducted the test for 4 groups of variables where all the variables are taken in their levels. The group members of each group are presented in Table 6 . The test results show that there is at least 1 cointegration equation in each group. The test runs with either linear deterministic trend or quadratic deterministic trend and with 1 lag interval (in first difference). The estimated results are presented in Table 6. 
Table 6: Results of Johansen Cointegration Test

\begin{tabular}{|c|c|c|c|}
\hline Group 1 & \multicolumn{3}{|c|}{ Ipolcon, Icrudepr, Igdp } \\
\hline Trend assumption: & \multicolumn{3}{|c|}{ Linear deterministic trend } \\
\hline No. of CE(s) & Trace Stat. & & \\
\hline None* & 49.03 & 29.80 & 0.0001 \\
\hline At most $1^{*}$ & 15.98 & 15.49 & 0.0423 \\
\hline At most 2 & 2.40 & 3.84 & 0.1217 \\
\hline Result: & \multicolumn{3}{|c|}{ Trace test indicates 2 cointegrating eqn(s) at the 0.05 level } \\
\hline Group 2 & \multicolumn{3}{|c|}{ Itax, Ipolcon } \\
\hline Trend assumption: & \multicolumn{3}{|c|}{ Quadratic deterministic trend } \\
\hline None* & 21.86 & 18.40 & 0.0157 \\
\hline At most $1^{*}$ & 9.53 & 3.84 & 0.0020 \\
\hline Result: & \multicolumn{3}{|c|}{ Trace test indicates 2 cointegrating eqn(s) at the 0.05 level } \\
\hline Group 3 & \multicolumn{3}{|c|}{ lconng, Ingprice, lavailng, lgdp } \\
\hline Trend assumption: & \multicolumn{3}{|c|}{ Linear deterministic trend } \\
\hline None* & 84.49 & 47.86 & 0.0000 \\
\hline At most $1^{*}$ & 40.75 & 29.80 & 0.0019 \\
\hline At most 2 & 6.07 & 15.49 & 0.6878 \\
\hline Result: & \multicolumn{3}{|c|}{ Trace test indicates 2 cointegrating eqn(s) at the 0.05 level } \\
\hline Group 4 & \multicolumn{3}{|c|}{ Itax, Ipolcon, Iconng } \\
\hline Trend assumption: & \multicolumn{3}{|c|}{ Quadratic deterministic trend } \\
\hline None* & 48.63 & 35.01 & 0.0010 \\
\hline At most $1^{*}$ & 24.19 & 18.40 & 0.0069 \\
\hline At most $2^{*}$ & 8.50 & 3.84 & 0.0036 \\
\hline
\end{tabular}

Source: Estimated

Time series tests show that all the variables are stationary at their first difference (or integrated of order 1) and they are cointegrated in the long run. According to time series econometrics suggested method for estimation of multivariate models using such type of variables is Fully Modified Ordinary Least Square (FM-OLS) (Wang and Wu 2012). Phillips and Hansen (1990) designed FM-OLS regression to provide optimal estimates of cointegrating regressions. The method modifies least squares to account for serial correlation effects and for the endogeneity in the regressors that result from the existence of a cointegrating relationship. FM estimator estimates conintegrating relations directly by modifying traditional OLS with corrections that take account of endogeneity and serial correlation. One reason the method has proved useful is that one can use the FM corrections to determine how important these effects are in an empirical application. One additional benefit of FM is that there is no need to be explicit about the configuration or the dimension of the stationary and nonstationary components in the system and without the need to pretest the data concerning these characteristics. FM procedure can be applied to models with cointegrated regressors and even stationary regressors without losing the method's good asymptotic properties. In Stata, cointreg command developed by Wang and Wu (2012) 
enables the estimation of cointegration regression using FM-OLS, Dynamic OLS (DOLS) and Canonical Cointegration Regression (CCR) methods. However, we have used FM-OLS in estimation of our models using annual data.

The result of the estimated equation 1 is presented in Table 7. It shows that there is an inverse relationship between consumption (sales) of petroleum products and price of crude oil. Since domestic prices of petroleum products depend on international crude oil price, any change in crude oil price will have inverse impact on domestic sales. In other words, price elasticity of petroleum products consumption in negative. Domestic prices of petroleum products depend on international crude petroleum price, exchange rate of Indian rupee visà-vis US dollar, and domestic taxes. Moreover, domestic prices of petroleum products (e.g., petrol, diesel, ATF) vary across States, depending on landed price of petroleum products at the state's border and state tax rates. Since there is no state-wise information of prices of petroleum products available in the public domain and given that prices of high value petroleum products (e.g., petrol, diesel) vary frequently, it is beyond the scope of the present study to compile information of petroleum prices across states over time. In absence of statewise prices of petroleum products, we have used international crude oil price (Indian basket) as representative of domestic prices. In an earlier study in India Agrawal (2015) multiplies international crude oil price (Indian basket) with exchange rate of Indian rupee vis-à-vis US dollar and then divide the product by Whole Sale Price (WPI) Index to get the domestic prices of petroleum products. However, in absence of state-specific WPI Index this exercise may not able to capture state-wise variations in domestic prices of petroleum products, so we have avoided it. Table 7 shows that with rising GDP, sales of petroleum products increase and with further rise in GDP sales fall. This finding confirms that income elasticity of consumption of petroleum products is positive. As income (GDP) rises, consumption increases, but it plateaus; if income rises further, consumption falls. dum0809 has positive impact on sales but dum1415 has a negative impact. Both the trends (linear and quadratic) have positive impact on sales. This implies that over the years petroleum consumption is increasing. Table 7 presents the KPSS (Kwiatkowski et al., 1992) test statistic for residual series and it shows the null hypothesis of stationary residuals cannot be rejected (Baum 2000).

Table 7 also shows that consumption of natural gas depends on price, availability and GDP. There is a positive relationship between price of natural gas and consumption. Since, price of natural gas is administered and market of natural gas is a monopoly of CPSUs, the underlying relationship between consumption and price may not reflect the actual consumer behaviour. Moreover, consumption of natural gas is India is constrained by availability and it is has been established in our estimated model. With rise in income (GDP) natural gas consumption falls (negative income elasticity) and as income (GDP) rises further consumption increases. dum0809 has positive impact on sales whereas dum1415 has negative impact. The residual series of the estimated model is stationary as it is confirmed by the KPSS test. However to project consumption of natural gas we need projection of natural gas price and future availability of natural gas. 
Table 7: Results of FM-OLS Estimations of Consumption of Petroleum Products and Natural Gas based on Annual Data

\begin{tabular}{|c|c|c|c|c|c|c|}
\hline Dependent variable & Ipolcon & & & Iconng & & \\
\hline Independent Variables & Coeff. & & & Coeff. & & S.E. \\
\hline lcrudepr & -0.057 & * & 0.001 & & & \\
\hline lngprice & & & & 0.202 & * & $2.1 \mathrm{E}-08$ \\
\hline lavailng & & & & 1.095 & * & $4.6 \mathrm{E}-08$ \\
\hline lgdp & 2.477 & * & 0.181 & -5.350 & * & $8.0 \mathrm{E}-07$ \\
\hline $\operatorname{lgdp} 2$ & -0.083 & $*$ & 0.006 & 0.113 & * & $2.9 \mathrm{E}-08$ \\
\hline dum0809 & 0.013 & * & 0.001 & 0.029 & * & $1.3 \mathrm{E}-08$ \\
\hline dum1415 & -0.031 & * & 0.001 & -0.147 & * & $2.2 \mathrm{E}-08$ \\
\hline linear trend & 0.051 & * & 0.002 & 0.262 & * & $3.0 \mathrm{E}-08$ \\
\hline quadratic trend & 0.001 & $*$ & 0.000 & & & \\
\hline constant & -6.804 & $*$ & 1.420 & 51.052 & * & $6.0 \mathrm{E}-06$ \\
\hline \multicolumn{7}{|l|}{ Diagnostic Statistics } \\
\hline No. of Obs & 15 & & & 15 & & \\
\hline Adj. R2 & 0.974 & & & 0.978 & & \\
\hline Standard Error (S.E.) & 0.032 & & & 0.055 & & \\
\hline Long Run S.E. & 0.005 & & & 0.000 & & \\
\hline \multicolumn{7}{|l|}{ FM-OLS Specifications } \\
\hline VAR lag & 1 & & & 1 & & \\
\hline Kernel & Quadratic spectral & & & Quadratic spectro & & \\
\hline Bandwith (andrews) & 1.308 & & & 1.085 & & \\
\hline \multicolumn{7}{|l|}{ Residual Test } \\
\hline KPSS Stat & 0.107 & & & 0.096 & & \\
\hline KPSS $1 \%$ Critical Value & 0.216 & & & 0.216 & & \\
\hline
\end{tabular}

Note: *-implies estimated z-stat is significant at 0.01 level.

We present the estimated and actual consumption of petroleum products and natural gas in Figures 3 and 4 respectively. The figures confirm that estimated models are able to capture the dynamics of consumptions and the estimation error varies between -2.84 percent to 3.72 percent for petroleum products and -4.75 percent to 13.11 percent for natural gas. 
Figure 3: Actual and Estimated Consumption of Petroleum Products ('000 tonne) based on Annual Data

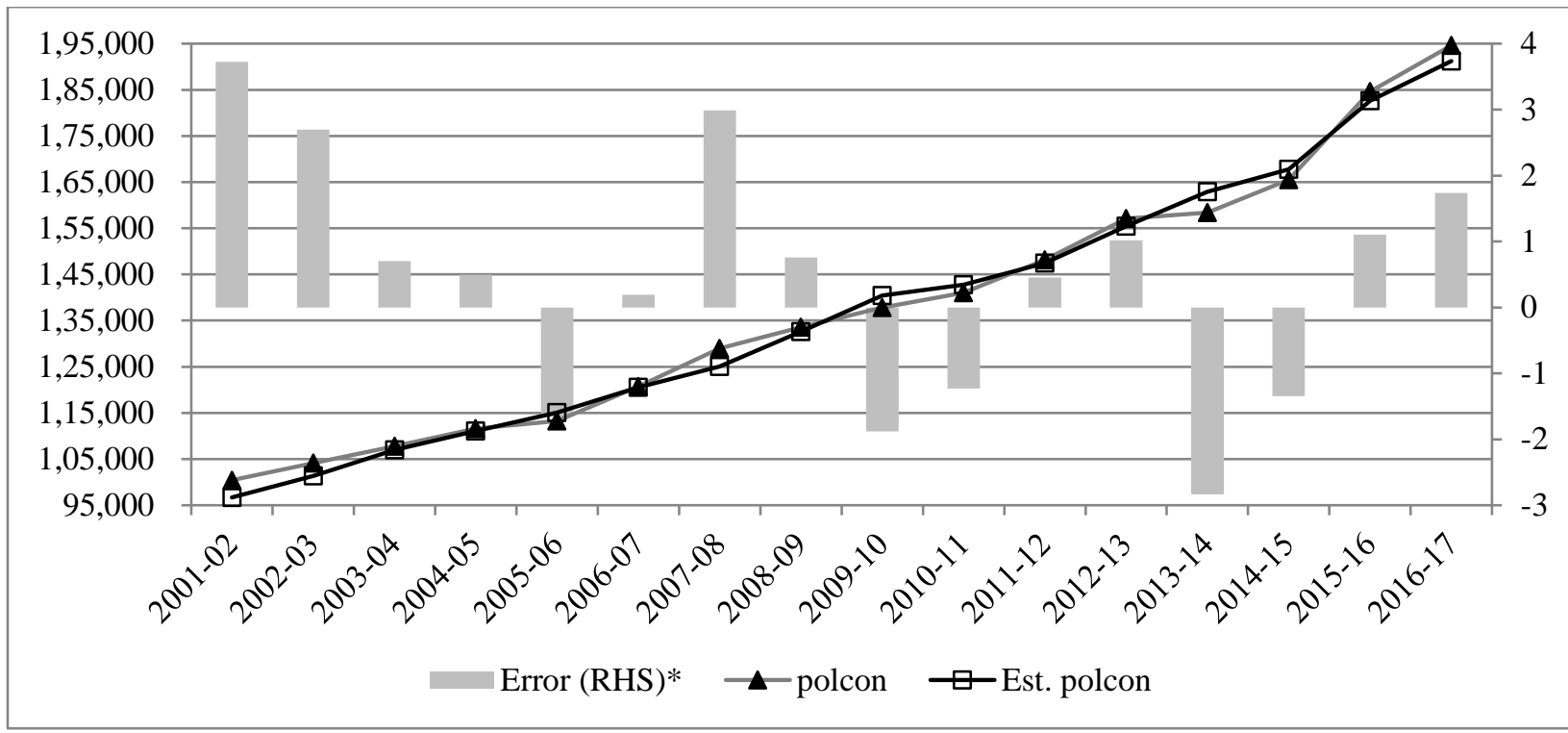

Note: ${ }^{*}$-Error $=($ Actual - Estimated $) /$ Actual ${ }^{*} 100$

Figure 4: Actual and Estimated Total Consumption of Natural Gas (in MMSCM)

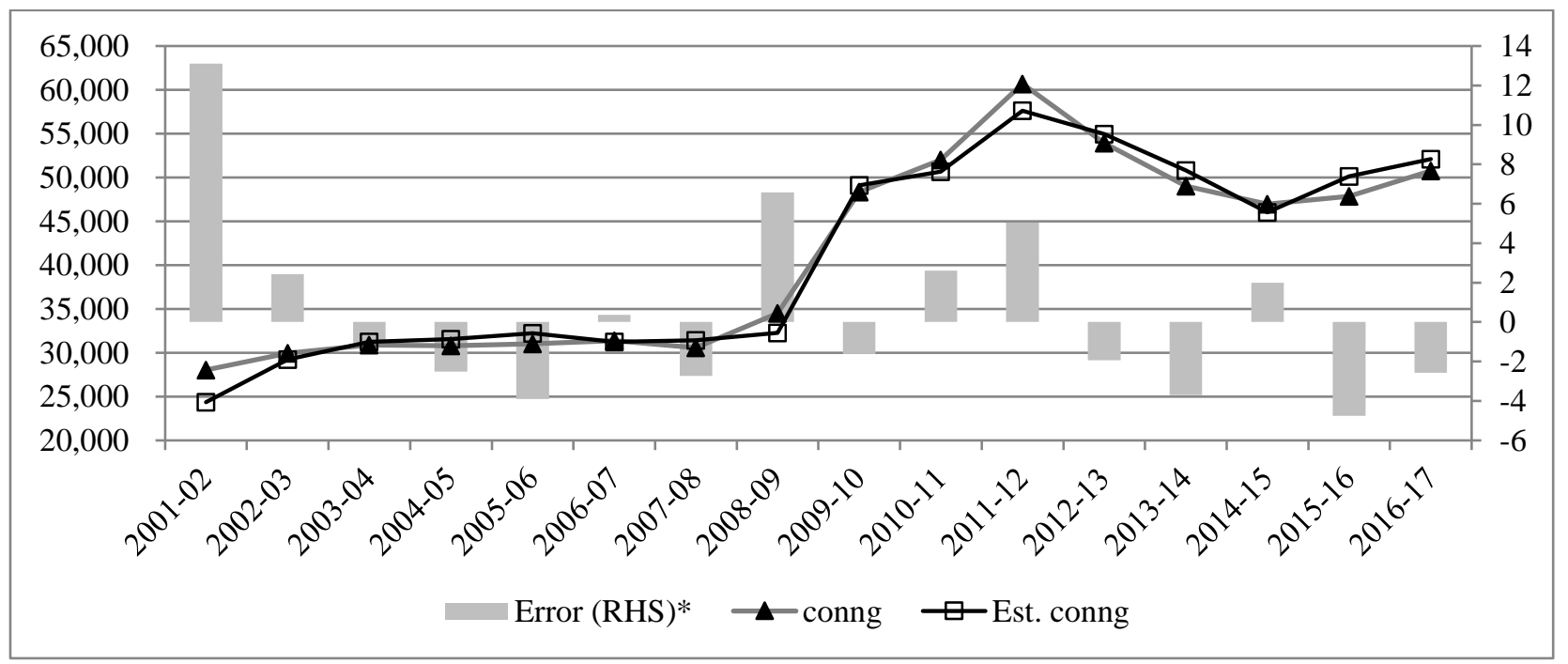

Note: ${ }^{*}$-Error $=($ Actual - Estimated $) /$ Actual*100

We present the results of estimated models of estimation of petroleum tax collection in Table 8. Model 1 is related to equation 2 and model 2 is related to equation 4 and the difference between the models is the inclusion of consumption of natural gas as a determinant of tax collection in model 2. In both the models, non-linear relationship between 
consumption of petroleum products and petroleum tax collection is found. Tax collection falls initially with rising consumption of petroleum products and it increases with further increase in consumption. Consumption of natural gas also has a negative impact on tax collection and we do not found any non-linear relationship between natural gas consumption and tax collection. In both the models dum0809 has negative impact on tax collection whereas dum1415 has positive impact in tax collection, as expected. There is non-linear relationship between time and tax collection. In both the models residuals are stationary.

Table 8: Results of FM-OLS Estimations of Petroleum Taxes Collection based on Annual Data

\begin{tabular}{|c|c|c|c|c|c|c|}
\hline \multirow{3}{*}{$\begin{array}{l}\text { Dependent variable } \\
\text { Independent Variables } \\
\text { lpolcon }\end{array}$} & \multicolumn{3}{|l|}{ Itax (Model 1) } & \multicolumn{3}{|l|}{ Itax (Model 2) } \\
\hline & Coeff. & & S.E. & Coeff. & & E. \\
\hline & -95.306 & * & $9.9 \mathrm{E}+00$ & -91.991 & * & 1.404 \\
\hline lpolcon2 & 4.076 & * & 4.1E-01 & 3.929 & * & 0.059 \\
\hline lconng & & & & -0.113 & * & 0.004 \\
\hline dum0809 & -0.16 & * & $1.1 \mathrm{E}-02$ & -0.164 & $*$ & 0.002 \\
\hline dum1415 & 0.075 & $*$ & $1.6 \mathrm{E}-02$ & 0.022 & $*$ & 0.003 \\
\hline linear trend & 0.219 & $*$ & $1.9 \mathrm{E}-02$ & 0.219 & $*$ & 0.003 \\
\hline quadratic trend & -0.009 & $*$ & $7.9 \mathrm{E}-04$ & -0.008 & $*$ & 0.000 \\
\hline constant & 567.865 & * & $5.9 \mathrm{E}+01$ & 550.359 & * & 8.399 \\
\hline \multicolumn{7}{|l|}{ Diagnostic Statistics } \\
\hline No. of Obs & 15 & & & 15 & & \\
\hline Adj. R2 & 0.992 & & & 0.992 & & \\
\hline Standard Error (S.E.) & 0.044 & & & 0.044 & & \\
\hline Long Run S.E. & 0.012 & & & 0.012 & & \\
\hline \multicolumn{7}{|l|}{ FM-OLS Specifications } \\
\hline VAR lag & 1 & & & 1 & & \\
\hline Kernel & Quadratic spectral & & & Quadratic spectral & & \\
\hline Bandwith (andrews) & 1.816 & & & 1.816 & & \\
\hline \multicolumn{7}{|l|}{ Residual Test } \\
\hline KPSS Stat & 0.090 & & & 0.115 & & \\
\hline KPSS 1\% Critical Value & 0.216 & & & 0.216 & & \\
\hline
\end{tabular}

Note: ${ }^{*}$-implies estimated z-stat is significant at 0.01 level.

Estimated and actual tax collection from petroleum taxes are presented in Figure 5 and 6 for model 1 and model 2 respectively. The estimated models are able to capture dynamics of tax collection effectively as estimated errors (presented in right hand scale of the figures) are low, except for the first year. Despite of limited data points and data limitations (e.g., domestic prices of petroleum products), estimation errors are less than 10 percent for both the models. 
Figure 5: Actual and Estimated Total Tax Collection from Petroleum Sector (Rs. Crore) - Model 1

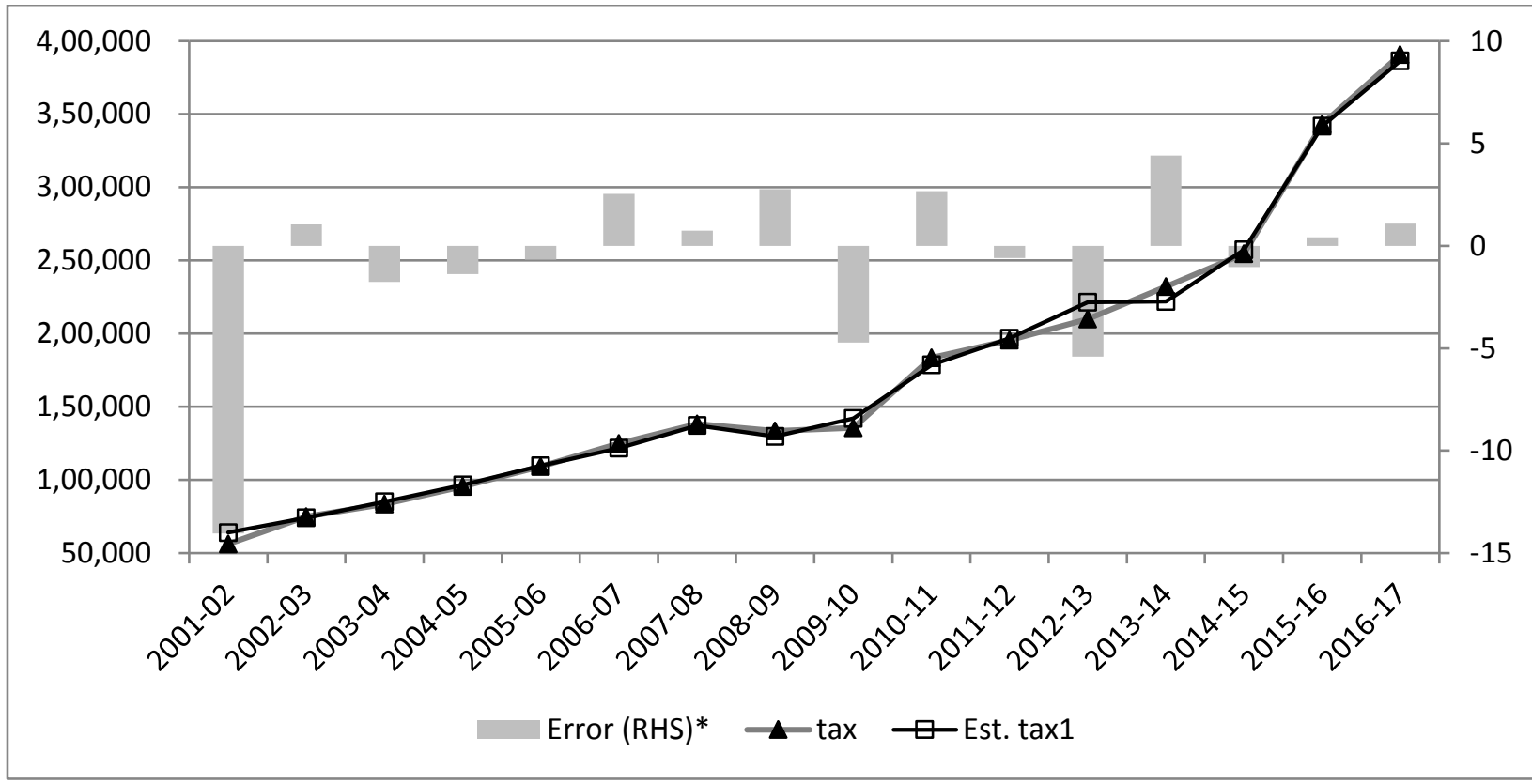

Note: ${ }^{*}$-Error $=($ Actual - Estimated $) /$ Actual ${ }^{*} 100$

Figure 6: Actual and Estimated Total Tax Collection from Petroleum Sector (Rs. Crore) - Model 2

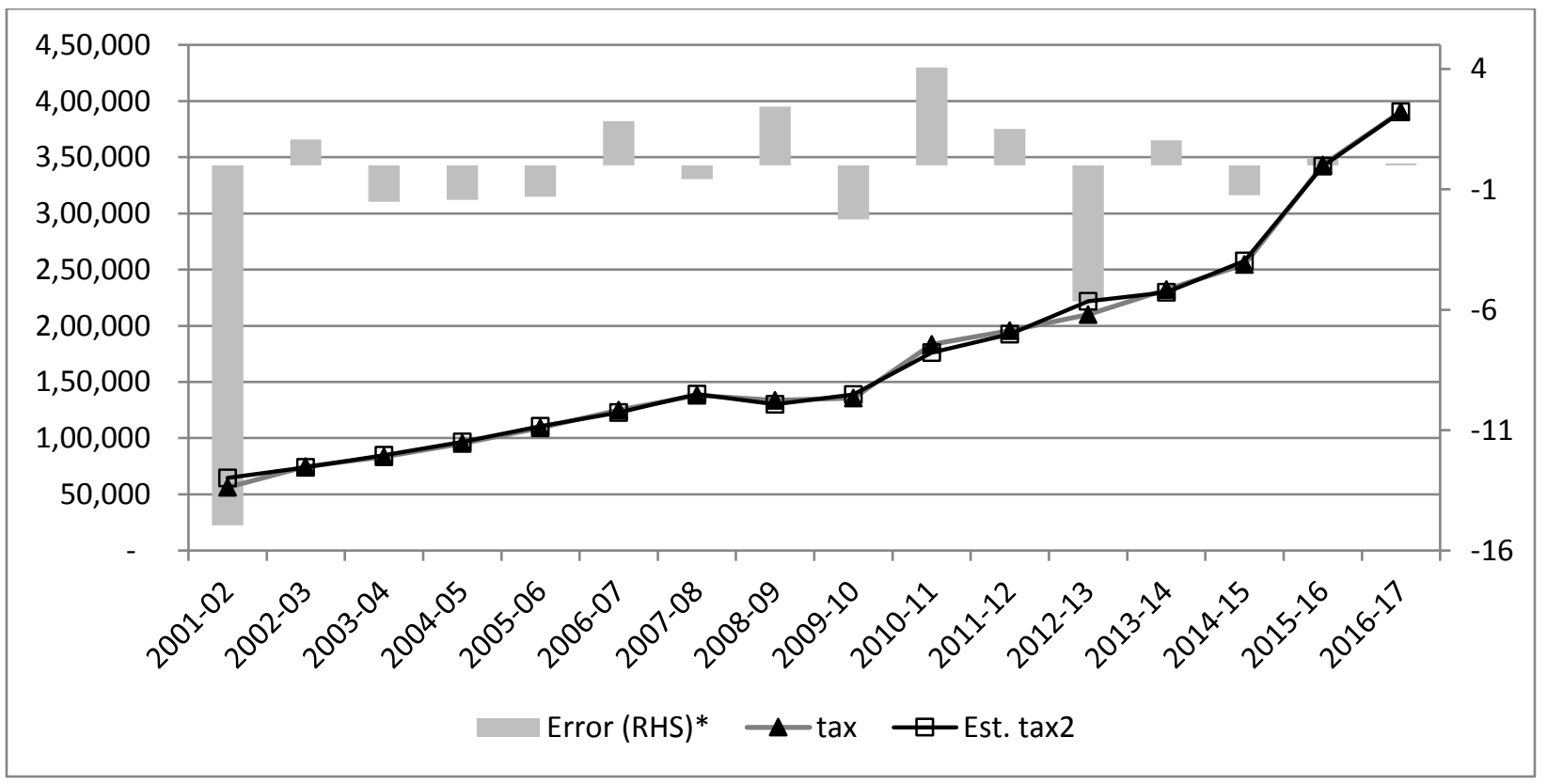

Note: $*$-Error $=($ Actual - Estimated $) /$ Actual $* 100$ 


\subsection{Models Based on Quarterly Data}

In this section we estimate the consumption (sales) function of petroleum products based on quarterly data of the variables presented in Table 9 for the period Q1 (April to June) of 2000-01 to Q4 (January- March) of 2018-19. Petroleum Policy Analysis Cell (PPAC) provides monthly sales of various petroleum products and monthly average price of crude petroleum (Indian basket). To match the quarterly data of nominal GDP at factor cost (or GVA at basic prices for 2011-12 series), we have aggregated monthly sales to obtain quarterly sales figures. We have derived quarterly average price of crude petroleum (Indian basket) from monthly average price for the respective quarters. However, PPAC does not provide state-wise quarterly sales of petroleum products which restrict us to estimate quarterly petroleum consumption function for states by using PPAC database.

It is expected that that with larger frequency of the dataset, estimated model could throw some new lights on the functional relationship as well as degree of association of the variables selected to estimate the consumption function of petroleum products. This exercise could also help to validate our results obtained from annual data series. Figure 7 shows that there is seasonality in the sales of petroleum products, as sales of petroleum products goes down in Q2 (July-September) as compared to other three quarters. We have introduced a dummy (dumq2, dumq2= 1 for Q2, 0 otherwise) in our estimations.

Table 9: Basic Statistics of Quarterly Data

\begin{tabular}{lccccc}
\hline \multicolumn{1}{c}{ Variable } & $\begin{array}{c}\text { No. of } \\
\text { Observation }\end{array}$ & Mean & Std. Dev & Min & Max \\
\hline $\begin{array}{l}\text { Consumption of Petroleum } \\
\text { Products ('000 tonne) (sales) }\end{array}$ & 76 & 35,863 & 8,894 & 24,295 & 54,508 \\
$\begin{array}{l}\text { Average Crude Oil Price (Indian } \\
\text { Basket) (USD/bbl) (crudeprice) }\end{array}$ & 76 & 63.6 & 29.9 & 18.8 & 118.8 \\
$\begin{array}{l}\text { GDP at Factor Cost (current prices, } \\
\text { 2004-05 series) (Rs. Crore) (gdp)* }\end{array}$ & 76 & $1,902,056$ & $1,249,263$ & 460,648 & $4,606,345$ \\
\hline
\end{tabular}

Note: *-Gross Value Added (GVA) at basic prices for 2011-12 series

Source: Online Database of Petroleum Policy Analysis Cell (PPAC) and EPWRF India Time Series

Database 
Figure 7: Quarterly Sales of Petroleum Products in India ('000 tonne)

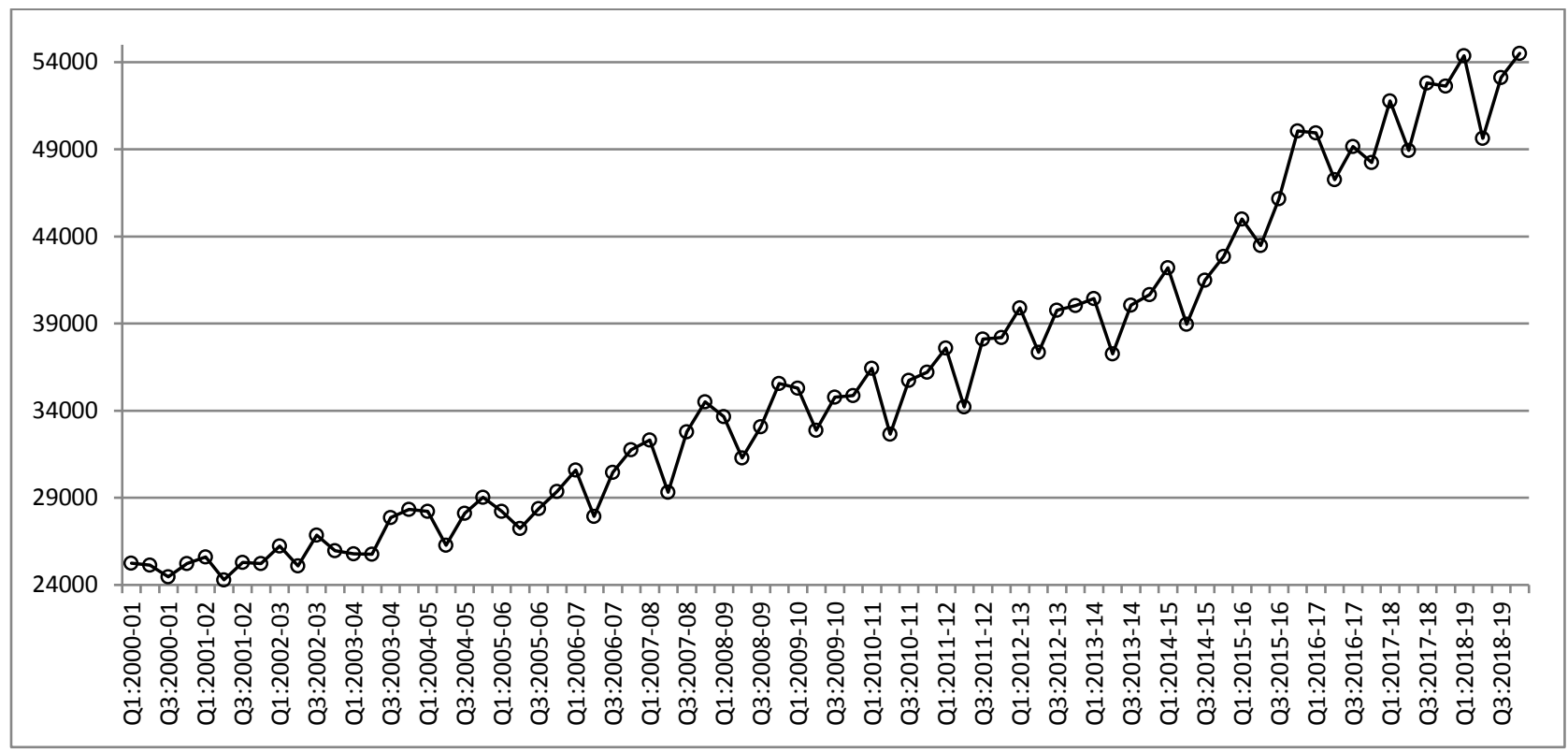

Source: Based on PPAC Online Database

\section{Unit Root Test}

Results of unit root test show that lcruedeprice is not stationary at level whereas PP test (with intercept and trend) shows that both lgdp and lsales are stationary at level with intercept and trend. According to ADF test both lgdp and lsales are not stationary at level. In the case of lgdp, first difference (with intercept and trend) is not stationary according to ADF test. According to PP test, all variables are stationery in all specifications in their first difference. To confirm the stationarity of lgdp and lsales in their levels, KPSS test is conducted and the test results show that both the variables are not stationary in their levels (Table 11). Therefore, it would not be erroneous to conclude that all variables are stationary at their first difference or I(1) series. 
Table 10: Results of Unit Root Test for Quarterly Data

\begin{tabular}{|c|c|c|c|c|c|c|c|c|c|}
\hline \multirow[t]{3}{*}{ Variable } & \multirow[t]{3}{*}{ Specification } & \multicolumn{4}{|c|}{ Level } & \multicolumn{4}{|c|}{ First Difference } \\
\hline & & \multicolumn{2}{|c|}{$\begin{array}{c}\text { Augmented } \\
\text { Dickey-Fuller test } \\
\text { statistic }\end{array}$} & \multicolumn{2}{|c|}{$\begin{array}{l}\text { Phillips-Perron } \\
\text { test statistic }\end{array}$} & \multicolumn{2}{|c|}{$\begin{array}{c}\text { Augmented } \\
\text { Dickey-Fuller test } \\
\text { statistic }\end{array}$} & \multicolumn{2}{|c|}{$\begin{array}{l}\text { Phillips-Perron } \\
\text { test statistic }\end{array}$} \\
\hline & & Statistic & p-value & Statistic & p-value & Statistic & $\mathrm{p}$-value & Statistic & $\mathrm{p}$-value \\
\hline \multirow[t]{3}{*}{ lcrudeprice } & No Intercept & 0.428 & 0.804 & 0.417 & 0.801 & -7.119 & 0.000 & -7.00 & 0.000 \\
\hline & Intercept & -1.755 & 0.400 & -1.799 & 0.378 & -7.093 & 0.000 & -6.97 & 0.000 \\
\hline & $\begin{array}{l}\text { Intercept and } \\
\text { Trend }\end{array}$ & -1.544 & 0.805 & -1.639 & 0.768 & -7.086 & 0.000 & -6.95 & 0.000 \\
\hline \multirow[t]{3}{*}{ lgdp } & No Intercept & 2.665 & 0.998 & 9.303 & 1.000 & -0.686 & 0.416 & -7.44 & 0.000 \\
\hline & Intercept & -0.801 & 0.813 & -0.407 & 0.902 & -2.965 & 0.043 & -12.16 & 0.000 \\
\hline & $\begin{array}{l}\text { Intercept and } \\
\text { Trend }\end{array}$ & -1.281 & 0.885 & -4.736 & 0.001 & -2.958 & 0.151 & -12.24 & 0.000 \\
\hline \multirow[t]{3}{*}{ lsales } & No Intercept & 3.837 & 1.000 & 4.696 & 1.000 & -1.953 & 0.049 & -12.12 & 0.000 \\
\hline & Intercept & 0.849 & 0.994 & 0.423 & 0.983 & -4.885 & 0.000 & -23.84 & 0.000 \\
\hline & $\begin{array}{l}\text { Intercept and } \\
\text { Trend }\end{array}$ & -2.575 & 0.293 & -6.645 & 0.000 & -5.031 & 0.001 & -28.33 & 0.000 \\
\hline
\end{tabular}

Source: Computed

Table 11: Results of Unit Root Test by using KPSS for Quarterly Data

\begin{tabular}{|c|c|c|c|}
\hline \multirow[t]{2}{*}{ Variable } & \multirow[t]{2}{*}{ Specification } & $\begin{array}{l}\text { Max lag order (bandwidth) is Zero, } \\
\text { Bartlett kernel }\end{array}$ & $\begin{array}{l}\text { Max lag order (bandwidth) is Zero, } \\
\text { quadratic spectral kernel }\end{array}$ \\
\hline & & \multicolumn{2}{|c|}{ H0: lgdp is trend stationary } \\
\hline \multirow{4}{*}{ lgdp } & Lag order & 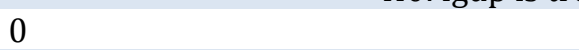 & 3 \\
\hline & Test Stat & 0.658 & 0.27 \\
\hline & $1 \%$ critical value & 0.216 & 0.216 \\
\hline & & \multicolumn{2}{|c|}{$\mathrm{H} 0$ : lsales is trend stationary } \\
\hline \multirow[t]{3}{*}{ lsales } & Lag order & 0 & 3 \\
\hline & Test Stat & 0.437 & 0.277 \\
\hline & $1 \%$ critical value & 0.216 & 0.216 \\
\hline
\end{tabular}

Source: Computed

\section{Cointergartion Test}

Johansen Cointegration Test is conducted to see if there is any long-run relationship among lsales, lcrudeprice and lgdp. The test results show that there is at least 1 cointegration equation. The test runs with linear deterministic trend and quadratic deterministic trend and with 1 lag interval (in first difference). The estimated results are presented in Table 6. 
Table 12: Results of Johansen Cointegration Test

\begin{tabular}{|c|c|c|c|c|c|c|}
\hline \multirow{2}{*}{$\begin{array}{l}\text { Trend assumption: } \\
\text { No. of CE(s) }\end{array}$} & \multicolumn{3}{|c|}{ Linear deterministic trend (restricted) } & \multicolumn{3}{|c|}{ Quadratic deterministic trend } \\
\hline & Trace Stat. & 0.05 Cr. Val. & Prob** $^{* *}$ & Trace Stat. & 0.05 Cr. Val. & Prob** $^{* *}$ \\
\hline None* & 43.12 & 42.92 & 0.05 & 41.97 & 35.01 & 0.01 \\
\hline At most 1 & 17.70 & 25.87 & 0.36 & 16.68 & 18.40 & 0.09 \\
\hline At most 2 & 3.67 & 12.52 & 0.79 & 3.10 & 3.84 & 0.08 \\
\hline Result: & \multicolumn{3}{|c|}{$\begin{array}{c}\text { Trace test indicates } 1 \text { cointegrating eqn } \\
\text { at the } 0.05 \text { level }\end{array}$} & \multicolumn{3}{|c|}{$\begin{array}{c}\text { Trace test indicates } 1 \text { cointegrating eqn at } \\
\text { the } 0.05 \text { level }\end{array}$} \\
\hline \multicolumn{7}{|c|}{$*$ denotes rejection of the hypothesis at the 0.05 level } \\
\hline **MacKinnon-Haug-I & chelis (1999) p & -values & & & & \\
\hline
\end{tabular}

We estimate cointegration regression using FM-OLS and the results are presented in Table 13. Two alternative specifications of the model are estimated and results show that current sale is positively and significantly related to last quarter's sales. This is a new finding as compared to models run on annual data. There is an inverse relationship between price of crude petroleum and current sale. In model 1, there is an inverse relationship between one quarter lag of lgdp and current sale whereas there is a positive relationship between lgdp ${ }^{2}$ and lsales. In model two, first difference of lgdp has positive impact on current sale. This implies that as GDP grows demand for petroleum product increases. In other words, income elasticity of petroleum sales is positive. Sales go down in Q2 and there is a positive linear trend. KPSS test confirms that residuals are stationary in both the models. The results show that with higher frequency of data, the functional relationship changes.

We present the actual and estimated consumption of petroleum products in Figure 8 based on estimates of model 1. It shows that estimated model is able to capture the dynamics of petroleum sales and the estimation error is less than 10 percent. Since data on quarterly tax collection from petroleum sector is not available, we are not able to estimate the revenue function based on quarterly data. Projection of future consumption (sales) of petroleum products based on estimated models will be contingent upon availability of quarterly projection of crude petroleum price and GDP growth. 
Table 13: Results of Estimation of Consumption of Petroleum Products based on Quarterly Data

\begin{tabular}{|c|c|c|c|c|c|c|c|}
\hline \multirow{3}{*}{$\begin{array}{l}\text { Dependent Variable } \\
\text { Model } \\
\text { Independent Variables }\end{array}$} & \multicolumn{3}{|l|}{ Isales } & \multicolumn{4}{|c|}{ Isales } \\
\hline & \multicolumn{3}{|c|}{ Model 1} & \multicolumn{4}{|c|}{ Model 2} \\
\hline & Coeff. & & S.E. & Coeff. & & & S.E. \\
\hline L1.lsales & 0.668 & ** & 0.055 & & 0.664 & ** & 0.060 \\
\hline lcrudeprice & -0.012 & $*$ & 0.005 & & -0.019 & $* *$ & 0.005 \\
\hline L1.lgdp & -0.154 & ** & 0.044 & & & & \\
\hline $\operatorname{lgdp2}$ & 0.005 & ** & 0.002 & & & & \\
\hline D1.lgdp & & & & & 0.157 & ** & 0.044 \\
\hline dumq2 & -0.087 & ** & 0.005 & & -0.086 & ** & 0.005 \\
\hline linear & 0.004 & $* *$ & 0.001 & & 0.004 & $* *$ & 0.001 \\
\hline constant & 4.602 & ** & 0.618 & & 3.467 & ** & 0.611 \\
\hline \multicolumn{8}{|l|}{ Diagnostic Statistics } \\
\hline No. of observations & 74 & & & & 74 & & \\
\hline Adj. R2 & 0.922 & & & & 0.945 & & \\
\hline S.E. & 0.068 & & & & 0.057 & & \\
\hline Long run S.E. & 0.016 & & & & 0.018 & & \\
\hline \multicolumn{8}{|l|}{ FM-OLS Specifications } \\
\hline VAR Lag & 1 & & & & 1 & & \\
\hline Kernel & quadratic spectral & & & quadra & pectral & & \\
\hline Bandwidth(andrews) & 1.513 & & & & 2.083 & & \\
\hline \multicolumn{8}{|l|}{ Residual Test } \\
\hline KPSS Stat (lag order 3, Kernel: qs) & 0.053 & & & & 0.062 & & \\
\hline KPSS Stat - 1\% Critical Value & 0.739 & & & & 0.739 & & \\
\hline
\end{tabular}

Source: Estimated 
Figure 8: Actual and Estimated Consumption of Petroleum Products (' 000 tonne) (FMOLS Model 1)

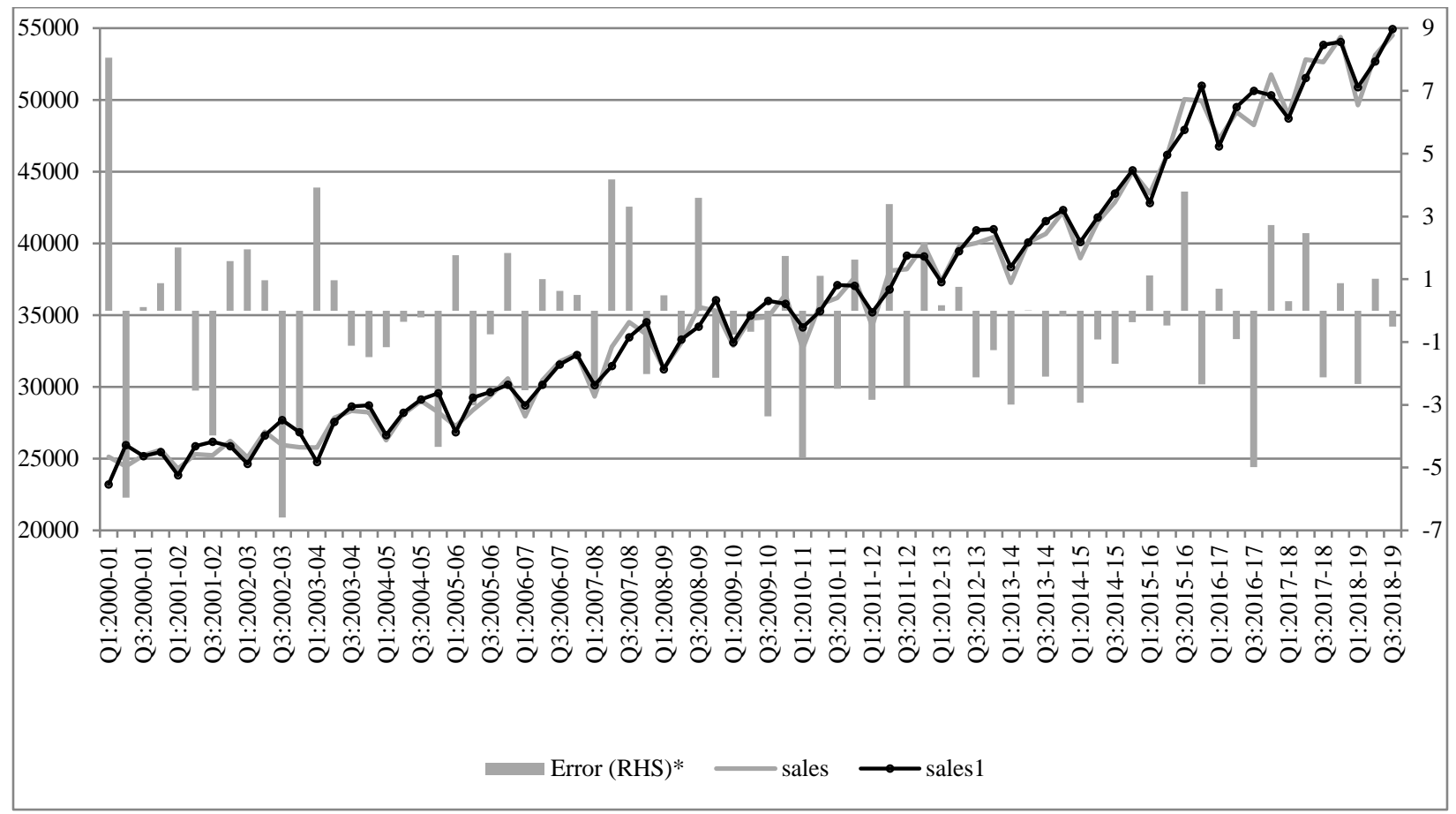

Note: ${ }^{*}$-Error $=($ Actual - Estimated $) /$ Actual ${ }^{*} 100$

\subsection{Models Based on Panel Data}

This part of the analysis is based on panel data of State-wise sales (consumption) of petroleum products, State Gross State Domestic Products (GSDP at factor cost), State-wise collection of taxes from petroleum products for the period 2001-02 to 2016-17. We have excluded both sales as well as tax collection from crude petroleum and natural gas in this exercise, as all states do not have opportunity to collect tax from crude petroleum (either indigenous or imported) and natural gas, as natural resource endowment is not homogeneous across Indian States. States where crude petroleum is explored collect sales tax/ CST and states where crude petroleum is imported for refining collect tax on entry. States having access to natural gas - either for domestic or industrial consumption - collect sales tax on natural gas. Average State tax collection from crude petroleum and natural gas together is only 6 percent of States' tax collection from petroleum sector during 2001-17. We have presented summary of the basic data in Appendix Table A1. The analysis is restricted to 17 major Indian States (Telangana is included into Andhra Pradesh). Since, state-wise prices of petroleum products vary, we have taken average annual Crude Oil Price (Indian Basket) (US\$/bbl) same across all states. 


\section{Panel Unit Root Test}

The results of panel unit root test show that all variables are stationary at their levels. To confirm the stationarity of the variables, we have conducted second generation panel unit root test, viz., Pesaran's CADF t bar test (Pesaran 2007).

\section{Table 14: Results of Panel Unit Root Tests}

\begin{tabular}{|c|c|c|c|c|c|c|c|c|c|c|c|}
\hline \multirow[t]{2}{*}{ Variable } & \multirow[t]{2}{*}{ Specification } & \multicolumn{2}{|c|}{ Common Root } & \multicolumn{6}{|c|}{ Individual Root } & \multicolumn{2}{|c|}{$\begin{array}{c}\text { Second } \\
\text { Generation }\end{array}$} \\
\hline & & $\begin{array}{l}\text { Levin- } \\
\text { Lin-Chu } \\
\text { Adj. t* }\end{array}$ & $\begin{array}{c}\text { p- } \\
\text { val. }\end{array}$ & \multicolumn{2}{|c|}{$\begin{array}{l}\text { Im-Pesaran- } \\
\text { Shin t bar }\end{array}$} & $\begin{array}{l}1 \% \\
\mathrm{cV}\end{array}$ & $\begin{array}{l}5 \% \\
\mathrm{cV}\end{array}$ & $\begin{array}{l}\text { Im-Pesaran-Shin } \\
\mathrm{Z}(\mathrm{t}) \text { tilda bar }\end{array}$ & p-val. & $\begin{array}{c}\text { Pesaran's } \\
\text { CADF t } \\
\text { bar@ } \\
\end{array}$ & p-val. \\
\hline \multirow[t]{2}{*}{ ltax } & $\begin{array}{l}\text { Individual } \\
\text { Intercept }\end{array}$ & -4.0116 & $* * *$ & -2.243 & $* * *$ & -2 & -1.86 & -3.0851 & $* * *$ & -2.26 & $* *$ \\
\hline & $\begin{array}{l}\text { Individual } \\
\text { Intercept \& } \\
\text { Trend }\end{array}$ & -1.9434 & $* *$ & -3.409 & $* * *$ & -2.63 & -2.49 & -5.0517 & $* * *$ & -2.431 & \\
\hline \multirow[t]{2}{*}{ lslaes } & $\begin{array}{l}\text { Individual } \\
\text { Intercept }\end{array}$ & 0.1174 & & -0.2314 & & -2 & -1.86 & 6.153 & & -2.167 & $* *$ \\
\hline & $\begin{array}{l}\text { Individual } \\
\text { Intercept \& } \\
\text { Trend }\end{array}$ & -4.76 & $* * *$ & -2.1165 & & -2.63 & -2.49 & -2.485 & $* * *$ & -2.209 & \\
\hline \multirow[t]{2}{*}{ lgsdp } & $\begin{array}{l}\text { Individual } \\
\text { Intercept }\end{array}$ & -5.6382 & $* * *$ & -0.482 & & -2.00 & -1.86 & 4.8157 & & -2.712 & $* * *$ \\
\hline & $\begin{array}{l}\text { Individual } \\
\text { Intercept \& } \\
\text { Trend }\end{array}$ & 2.9746 & & -1.4546 & & -2.63 & -2.49 & 0.2049 & & -2.791 & $* *$ \\
\hline
\end{tabular}

Note: ***-implies significant at 0.01 level and **-implies significant at 0.05 level. @ - see Pesaran (2007)

Unit root tests show that variables are level stationary either with or without trends. For such type of data, we could estimate models like panel feasible generalised least square (FGLS), Generalised Method of Moments (GMM) or panel pooled mean group (PMG) estimation regression as developed by Pesaran, Shin and Smith (1999).

We use a panel error correction model and estimate this model by pooled mean group estimator (PMG) by using xtpmg command in STATA, as developed by Blackburne III and Frank (2007). The benefit of this approach is that it allows for heterogeneity in parameters in sales as well as tax regressions. In addition, PMG distinguishes between the short and longrun effect of independent variables on sales / tax. The result shows a significant and negative long-run relationship between petroleum price and consumption of petroleum products (Table 15). The short-run result differs from the long-run and it may be due to homogeneity in crude price across States, as in absence of state-wise prices of petroleum products we have taken same crude price across States. With rising GSDP, petroleum consumption increases and with further increase in GSDP it falls. There is non-linear trend in the long run relationship and dum 1415 is found negative and significant. The PMG model allows for heterogeneous short-run dynamics and common long-run price and income elasticities. We also run mean group (MG) and dynamic fixed effect (DFE) estimates using xtpmg command, 
however Hausman's specification test shows PMG model is superior to other models. We estimate state-specific predicted value of D1.lsales using short-run effects model.

Table 16 presents estimation of petroleum tax collection based on panel data. The result shows that tax collection is positively and significantly dependent on sales/ consumption of petroleum products. Tax collection has positive and significant linear trend which implies that with time tax collection increases. Both dum0809 and dum1415 have negative and significant impacts on tax collection. This shows that after 2014-15, though overall tax collection from petroleum sector improves, there is negative impact for state tax collection from the petroleum products. States are not at per with the Union government to take the benefits of lower international price of crude petroleum, as the benefit of lower crude oil price is capitalised by the union government in terms of increasing the Union excise duty on petroleum products. For states landed price of petroleum products has gone up which may have benefitted States' tax collection marginally (as States taxes are ad valorem) but left no room to increase state taxes on petroleum products. Given political costs associated with increase in petroleum prices, States avoided to increase tax rates on petroleum products. Estimation based on panel data could help in taking up state-specific estimation of petroleum consumption function and tax collection. If projections of GSDP and crude price are available, this analysis could help to project consumption of petroleum products and tax collection thereof.

Table 15: Results of Estimation of Consumption of Petroleum Products based on Panel Data

\begin{tabular}{|c|c|c|c|}
\hline \multirow[t]{2}{*}{ Dependent Variable } & \multicolumn{3}{|l|}{ D1.lsales } \\
\hline & Coef. & & Std. Error \\
\hline \multicolumn{4}{|l|}{ Long-Run Effects } \\
\hline lcrudepr & -0.159 & *** & 0.009 \\
\hline lgsdp & 2.730 & *** & 0.519 \\
\hline lgsdp2 & -0.035 & ** & 0.016 \\
\hline time & -0.089 & *** & 0.007 \\
\hline time2 & -0.002 & *** & 0.000 \\
\hline dum1415 & -0.012 & $* * *$ & 0.004 \\
\hline \multicolumn{4}{|l|}{ Short-Run Effects } \\
\hline Error Correction Coefficient & -0.640 & *** & 0.093 \\
\hline D1.lcrudepr & -0.020 & & 0.027 \\
\hline D2.lcrudepr & 0.031 & * & 0.018 \\
\hline D1.lgdp & 15.842 & *** & 3.079 \\
\hline D2.lgdp & -14.019 & *** & 4.450 \\
\hline D1.lgdp2 & -0.479 & *** & 0.092 \\
\hline D2.lgdp2 & 0.409 & $* * *$ & 0.133 \\
\hline Constant & -16.579 & $* * *$ & 2.383 \\
\hline No. of Observation & 238 & & \\
\hline No. of Groups & 17 & & \\
\hline Average Obs. per Group & 14 & & \\
\hline Log likelihood & 530.031 & & \\
\hline
\end{tabular}


Table 16: Results of Estimation of Tax Collection from Petroleum Products based on Panel Data

\begin{tabular}{|c|c|c|c|}
\hline \multirow[t]{2}{*}{ Dependent Variable } & \multicolumn{3}{|l|}{ D1.Itax } \\
\hline & Coef. & & Std. Error \\
\hline \multicolumn{4}{|l|}{ Long-Run Effects } \\
\hline lsales & 0.702 & *** & 0.083 \\
\hline time & 0.087 & $* * *$ & 0.005 \\
\hline dum0809 & -0.214 & $* * *$ & 0.029 \\
\hline dum1415 & -0.122 & $* * *$ & 0.027 \\
\hline \multicolumn{4}{|l|}{ Short-Run Effects } \\
\hline Error Correction Coefficient & -0.511 & $* * *$ & 0.040 \\
\hline D1.Isales & -0.185 & $* * *$ & 0.105 \\
\hline Constant & 3.055 & $* * *$ & 0.247 \\
\hline No. of Observation & 255 & & \\
\hline No. of Groups & 17 & & \\
\hline Average Obs. per Group & 15 & & \\
\hline Log likelihood & 300.790 & & \\
\hline
\end{tabular}

Note: ${ }^{* * *}$ indicates estimated z-stat is significant at 0.01 level

\section{Projections of Petroleum Consumption and Petroleum Tax Collection}

To project sales of petroleum products till 2024-25, we need forecasts of crude petroleum price and GDP growth for the period 2017-25. Since PPAC provides month-wise average price of crude petroleum (Indian Basket) till March 2019, we depend on the World Bank's Commodity Market Outlook to get the projection of global average crude oil price for the period 2019-25. The World Bank projects global average crude oil price till 2030 and it is simple average of three spot prices, viz., Dated Brent, West Texas Intermediate and Dubai Fateh (World Bank 2019). To understand the relationship between World Bank's global average crude oil price and price of Indian basket of crude oil, ${ }^{6}$ we have plotted two price series for the period April 2000 to March 2018 in Figure 9. It shows that there are marginal differences in two prices but they have similar trends. Therefore, considering World Bank's forecast of average global price of crude oil as representative of price of Indian basket of crude for the period 2019-20 to 2024-25 may not be an erroneous assumption.

\footnotetext{
${ }^{6}$ The Indian basket of Crude Oil represents a derived basket comprising of Sour grade (Oman \& Dubai average) and Sweet grade (Brent Dated) of Crude oil processed in Indian refineries in the ratio of 71.03:28.97 during 2016-17. However, the ratio has changed over time - from 57:43 in 2001-02 to 71.03:28.97 in 2016-17.
} 
Figure 9: Comparison of Global Average Crude Oil Price and Crude Oil Price (Indian Basket) (US\$/bbl)

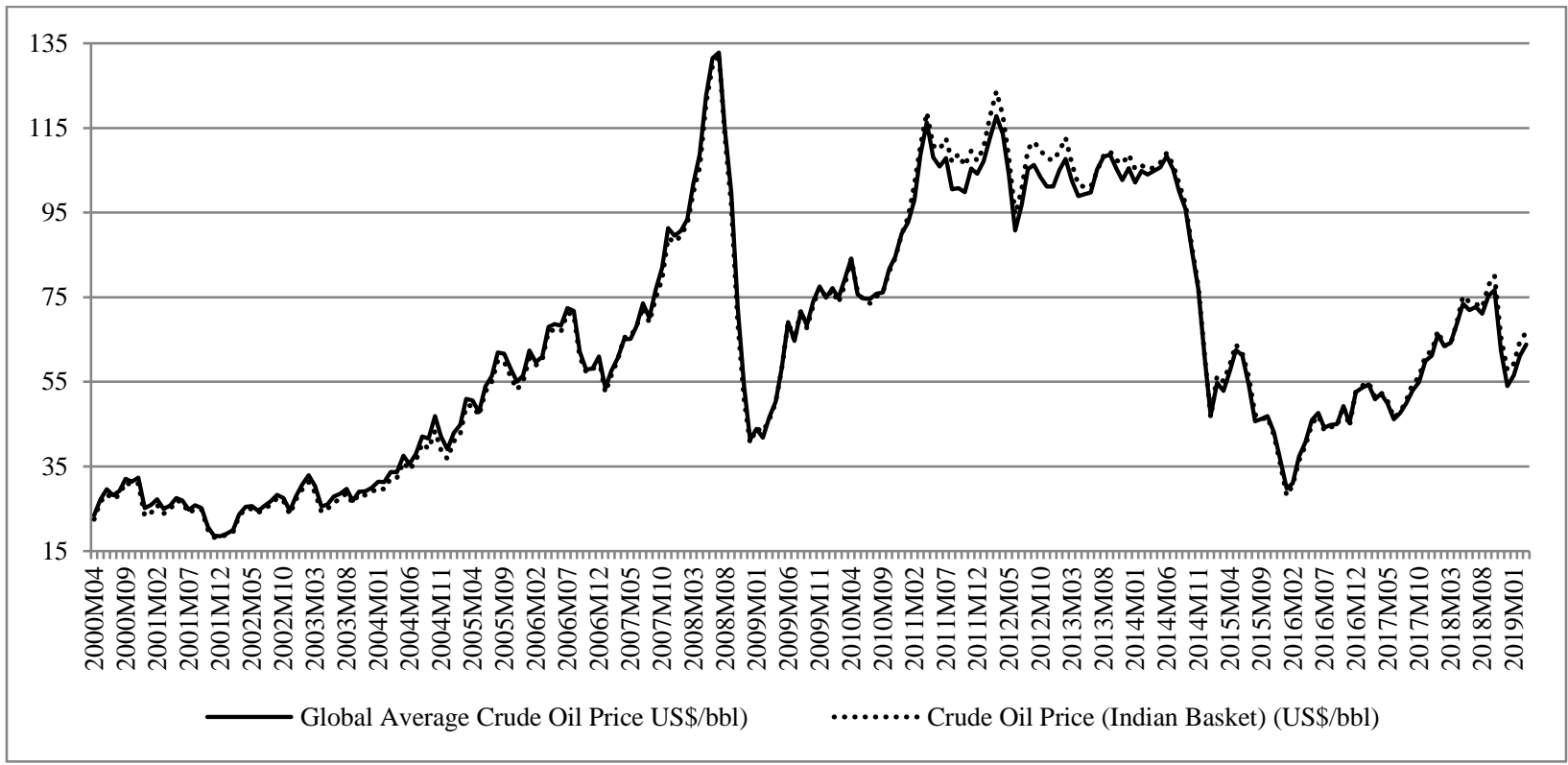

Source: For World Bank's Data http://pubdocs.worldbank.org/en/561011486076393416/CMOHistorical-Data-Monthly.xlsx and for Indian Data - PPAC Website (last accessed on 1 July 2019)

GVA at Basic Prices (both at current and constant prices, 2011-12 series) is available from EPWRF Indian Time Series Database up to 2018-19. International Monetary Fund (IMF) projects India's real GDP growth for the period of our projection (i.e., 2019-20 to 2024-25) in the World Economic Outlook Database. ${ }^{7}$ In the same database, IMF also projects India's inflation, based on average consumer price. We have relied on these estimates to project nominal GDP growth rate for the period 2019-25 (Table 17). However, depending on alternative sources of GDP projection, alternative scenarios can be created.

${ }^{7}$ https://www.imf.org/external/pubs/ft/weo/2019/01/weodata/index.aspx 
Table 17: Projection of GDP Growth based on IMF's World Economic Outlook Database

\begin{tabular}{|c|c|c|c|c|c|c|c|}
\hline \multirow[t]{2}{*}{ Year } & \multicolumn{2}{|c|}{$\begin{array}{l}\text { GVA at Basic Prices (at } \\
\text { Current Prices, 2011-12 } \\
\text { Series) }\end{array}$} & \multicolumn{2}{|c|}{$\begin{array}{c}\text { GVA at Basic Prices (at } \\
\text { Constant Prices, 2011-12 } \\
\text { Series) }\end{array}$} & \multirow[t]{2}{*}{$\begin{array}{c}\text { Inflation } \\
\text { (\%) }\end{array}$} & \multirow{2}{*}{$\begin{array}{c}\text { Growth } \\
\text { Projections } \\
\text { (Real, \%) } \\
\text { (WEO, IMF, } \\
\text { Apr-2019) }\end{array}$} & \multirow{2}{*}{$\begin{array}{l}\text { Consumer } \\
\text { Price } \\
\text { Inflation } \\
\text { Projection } \\
\text { (\%)(WE0, } \\
\text { IMF, Apr- } \\
\text { 2019) }\end{array}$} \\
\hline & Rs. Crore & $\begin{array}{c}\text { Growth } \\
\text { Rate (\%) }\end{array}$ & Rs. Crore & $\begin{array}{c}\text { Growth } \\
\text { Rate (\%) }\end{array}$ & & & \\
\hline (1) & (2) & (3) $(7+8)$ & (4) & (5) & (6) (3-5) & (7) & (8) \\
\hline 2011-12 & $8,106,946$ & & $8,106,947$ & & & & \\
\hline 2012-13 & $9,202,692$ & 13.5 & $8,546,277$ & 5.42 & 8.10 & & \\
\hline 2013-14 & $10,363,153$ & 12.6 & $9,063,647$ & 6.05 & 6.56 & & \\
\hline 2014-15 & $11,481,795$ & 10.8 & $9,719,024$ & 7.23 & 3.56 & & \\
\hline 2015-16 & $12,566,646$ & 9.4 & $10,503,348$ & 8.07 & 1.38 & & \\
\hline 2016-17 & $13,935,917$ & 10.9 & $11,318,972$ & 7.77 & 3.13 & & \\
\hline 2017-18 & $15,482,715$ & 11.1 & $12,104,165$ & 6.94 & 4.16 & & \\
\hline 2018-19 & $17,241,154$ & 11.4 & $12,887,661$ & 6.47 & 4.88 & & \\
\hline 2019-20* & $19,068,716$ & 11.14 & & & & 7.26 & 3.88 \\
\hline 2020-21* & $21,204,413$ & 11.73 & & & & 7.49 & 4.25 \\
\hline 2021-22* & $23,685,329$ & 11.97 & & & & 7.74 & 4.23 \\
\hline $2022-23^{*}$ & $26,503,883$ & 11.91 & & & & 7.73 & 4.18 \\
\hline $2023-24^{*}$ & $29,657,845$ & 11.83 & & & & 7.74 & 4.09 \\
\hline $2024-25^{*}$ & $33,157,471$ & 11.73 & & & & 7.74 & 3.99 \\
\hline
\end{tabular}

Note: *-Projected

Source: EPWRF India Time Series Database and IMF's World Economic Outlook Database

Based on projection of crude oil price and growth rate of nominal GDP/GVA, as an illustration we forecast sales of petroleum products (polcon) for the period 2019-20 to 202425 by using the estimate presented in Table 5 . In the next step, we project total tax collection from petroleum sector based on Model 1 of Table 8. Similar projection could also be made based on other models, provided projected series are available for other variables. The results show that India's consumption of petroleum products will grow at an annual average growth rate of 4.4 percent and tax collection from petroleum sector will grow at an annual average growth rate of 3.5 percent during 2019-20 to 2024-25. 
Figure 10: Actual, Estimated and Projected Consumption of Petroleum Products in India* ('000 tonne)

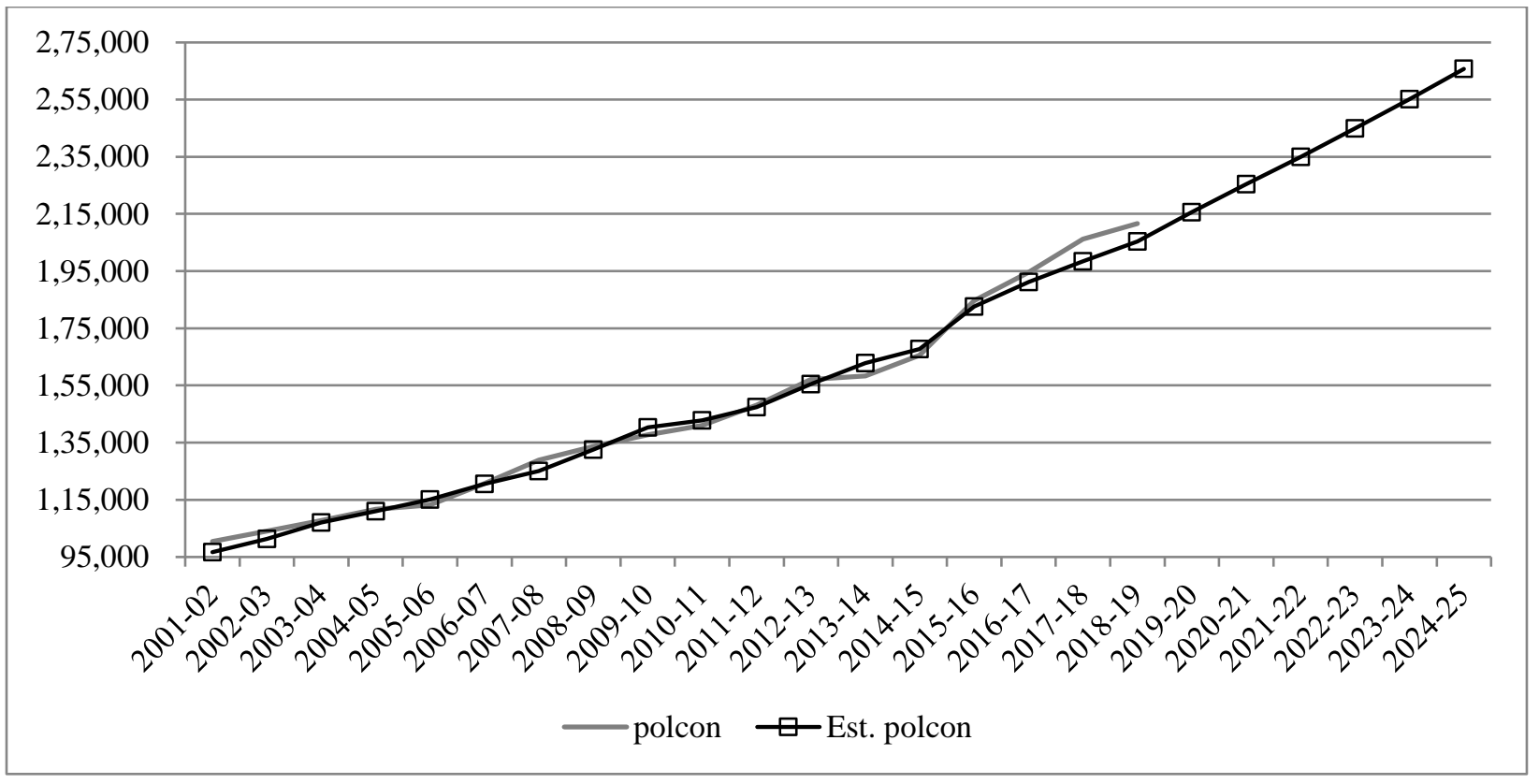

Note: *-Estimated and Projected Values are based on Model 1 of Annual Data

Figure 11: Actual, Estimated and Projected Tax Collection from Petroleum Sector in India*

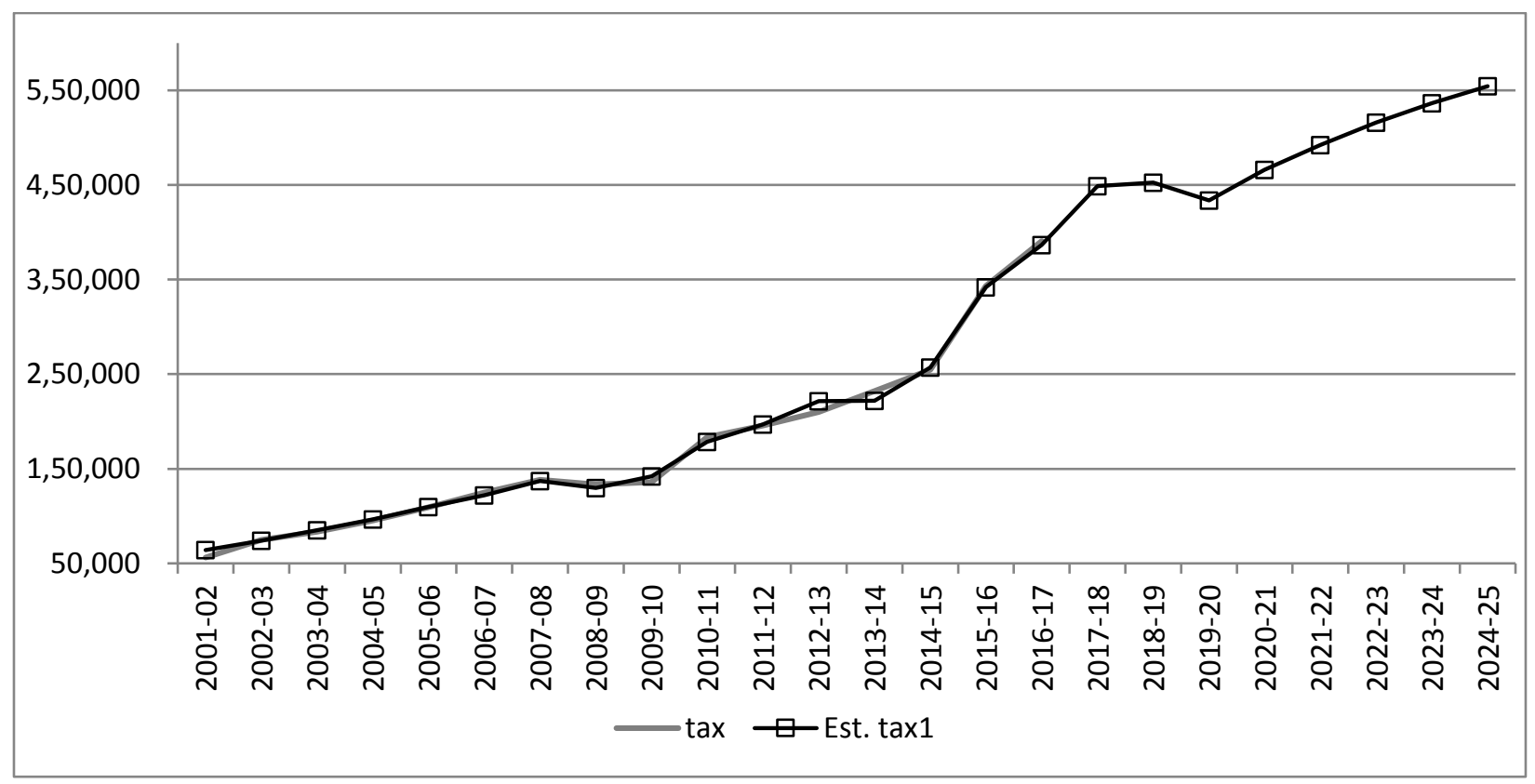

Note: *-Estimated and Projected Values are based on Model 1 of Annual Data 
The projections are based on the assumption that both petroleum pricing and taxation policies of the government will remain unchanged till 2024-25 and there will be no consumer behaviour changes in consumption of petroleum products. However, given the recent decision of the Union government to promote electric vehicles (EVs), the situation may differ in 2024-25 depending on penetration of EVs and corresponding fall in consumption of petroleum products.

\section{Conclusions}

The result of the estimated model based on annual data shows that there is an inverse relationship between consumption (sales) of petroleum products and price of crude oil. In other words, price elasticity of petroleum products consumption in negative. With rising income (GDP), sales of petroleum products increase and with further rise in GDP, sales fall. This finding confirms that income elasticity of consumption of petroleum products is positive. As income (GDP) rises, consumption increases, but it plateaus; if income rises further, consumption falls. Reduction of Union excise duty as a part of fiscal stimulus package during 2008-09 has positive impact on sales whereas increase in UED aftermath of fall international crude oil price in 2014-15 has a negative impact on sales. Over the years petroleum consumption is increasing and growth in consumption is increasing.

The result shows a positive relationship between price of natural gas and consumption. Since, price of natural gas is administered and market of natural gas is a monopoly of CPSUs, the underlying relationship between consumption and price may not reflect the actual consumer behaviour. Moreover, consumption of natural gas is India is constrained by availability and it is has been established in our estimated model. With rise in income (GDP) natural gas consumption falls (negative income elasticity) and as income (GDP) rises further consumption increases. Natural gas consumption has increased during 2008-10 whereas it has gone down after 2014-15. The estimations based on annual data are able to capture the dynamics of consumptions and the estimation error varies between -2.84 percent to 3.72 percent for petroleum products and -4.75 percent to 13.11 percent for natural gas.

There is a non-linear relationship between consumption of petroleum products and petroleum tax collection. Tax collection falls initially with rising consumption of petroleum products and it increases with further increase in consumption. Consumption of natural gas also has a negative impact on tax collection and we do not found any non-linear relationship between natural gas consumption and tax collection. There is non-linear relationship between time and tax collection. Despite of limited data points and data limitations, estimation errors are less than 10 percent.

Estimations based on quarterly data shows that there is seasonality in the sales of petroleum products, as sales of petroleum products go down in Q2 (July-September) as compared to other three quarters. There is an inverse relationship between price of crude petroleum and current sale. An inverse relationship between one quarter lag of GDP and 


\section{Working Paper No. 279}

current sale is found. There is a positive relationship between GDP2 and current sales. First difference of GDP has positive impact on current sale in an alternative model. This implies that as GDP grows demand for petroleum product increases. Sale goes down in Q2 and there is a positive linear trend. The results show that with higher frequency of data the functional relationship changes. However, projection of sales based on these models requires quarterly projection of crude petroleum price and GDP.

The result of panel data model shows a significant and negative long-run relationship between petroleum price and consumption of petroleum products. The short-run result differs from the long-run and it may be due to homogeneity in crude price across States, as state-wise prices of petroleum products are not available we have taken same crude price across States. With rising GSDP (State GDP) petroleum consumption increases and with further increase in GSDP it falls. There is non-linear trend in the long run relationship and sales fall aftermath of 2014-15.

Estimation of petroleum tax collection based on panel data shows that tax collection is positively and significantly dependent on sales/ consumption of petroleum products. Tax collection has positive and significant linear trend which implies that with time tax collection increases. After 2014-15, though overall tax collection from petroleum sector improves, there is negative impact for state tax collection from the petroleum products. States are not at per with the Union government to take the benefits of lower international price of crude petroleum, as the benefit of lower crude oil price is capitalised by the union government in terms of increasing the Union excise duty on petroleum products. For states landed price of petroleum products has gone up which may have benefitted States' tax collection marginally (as State petroleum taxes are ad valorem) but left no room to increase state taxes on petroleum products. Given political costs associated with increase in petroleum prices, States avoided to increase tax rates on petroleum products. Estimation based on panel data could help in taking up state-specific estimation of petroleum consumption function and tax collection. If projections of GSDP and crude price are available, this analysis could help to project consumption of petroleum products and tax collection at state level.

The present study would be useful for policy as future demands for petroleum products will generate demands for import of crude petroleum, investments in petroleum reserve, refining capacity and associated sectors - like petroleum transportation (e.g., pipeline) and distribution infrastructure, other chemicals and inputs required in petroleum refineries - and manpower/ skill development. Projection of petroleum taxes forms an inseparable part of budgeting exercise for many countries. It is expected that the present exercise could help both the Union and State governments in projecting petroleum tax collection in their budgeting exercise. 


\section{References}

Agrawal, Pradeep (2015), "India's petroleum demand: estimations and projections", Applied Economics, 47(12):1199-1212.

Berwick, Mark and Don Malchose (2012), "Forecasting North Dakota Fuel Tax Revenue and License and Registration Fee Revenue", Upper Great Plains Transportation Institute, North Dakota State University, Fargo, North Dakota.

Blackburne III, Edward F. and Mark W. Frank (2007), "Estimation of nonstationary heterogeneous panels", The Stata Journal, 7(2):197-208.

Christopher F Baum (2000): "KPSS: Stata module to compute Kwiatkowski-Phillips-SchmidtShin test for stationarity". Available at: https://ideas.repec.org/cgibin/htsearch?q=KPSS\%3A+Stata+module+to+compute+Kwiatkowski-PhillipsSchmidt-Shin+test+for+stationarity (last accessed on 29 July 2019).

Daniel, Philip (undated), "Petroleum Revenue Management: An Overview", Second Draft, Study prepared for the World Bank and ESMAP. Available at: http://www1.worldbank.org/publicsector/pe/ExtractiveIndustriesCourse/PhilipD aniel-Paper.pdf (last accessed on 23 July 2019).

Kwiatkowski, D., P.C.B. Phillips, P. Schmidt and Y. Shin (1992), "Testing the null of stationarity against the alternative of a unit root: How sure are we that economic time series have a unit root?", Journal of Econometrics, 54 (1-3): 159-178.

Ministry of Petroleum and Natural Gas (MoP\&NG) (2010 to 2018), "Indian Petroleum and Natural Gas Statistics 2009-10 to 2017-18", MoP\&NG, Government of India, New Delhi.

Mukherjee, S. (2019a), "Whether States have Capacity to Sustain Projected Growth in GST Collection during the Compensation Period?" Working Paper No. 275, National Institute of Public Finance and Policy (NIPFP), New Delhi, July 2019.

(2019b), "Inter-Governmental Fiscal Transfers in the Presence of Revenue Uncertainty: The Case of Goods and Services Tax (GST) in India", Working Paper No. 255, National Institute of Public Finance and Policy (NIPFP), New Delhi, March 2019. (2015), "Present State of Goods and Services Tax (GST) Reform in India", Working Paper No. 06/2015, Tax and Transfer Policy Institute, Crawford School of Public Policy, Australian National University, Canberra, Australia.

Mukherjee, S. and R. Kavita Rao (2019), "Decades of Indirect Tax Reforms in India - A Journey towards Goods and Services Tax (GST)", in Rao, R. Kavita and S. Mukherjee (2018), Evolution of Goods and Services Tax (GST) in India, New Delhi: Cambridge University Press.

(2015), "Policy options for including petroleum, natural gas and electricity in the Goods and Services Tax", Economic and Political Weekly, 50(9): 98-107. 
Parikh, Jyoti, Pallavi Purohit and Pallavi Maitra (2007), "Demand projections of petroleum products and natural gas in India", Energy, 32(10):1825-1837.

Pesaran, M. Hashem (2007), "A simple panel unit root test in the presence of cross-section dependence", Journal of Applied Econometrics, 22(2): 265-312.

Pesaran, M. Hashem, Yongcheol Shin and Ron P. Smith (1999), "Pooled Mean Group Estimation of Dynamic Heterogeneous Panels", Journal of the American Statistical Association, 94(446): 621-634.

Philips, P.C.B. and B.E. Hansen (1990), "Statistical inference in instrumental variables regression with I(1) processes", Review of Economic Studies, 57(1): 99-125.

Stephens, Thomas Kojo (2019), "Framework for petroleum revenue management in Ghana: current problems and challenges", Journal of Energy \& Natural Resources Law, 37(1): 119-143.

Sunley, E.M., T. Baunsgaard and D. Simard (2002), "Revenue from the Oil and Gas Sector: Issues and Country ", Available at: http://siteresources.worldbank.org/INTTPA/Resources/SunleyPaper.pdf (last accessed on 23 July 2019).

Wang, Qunyong and $\mathrm{Na} \mathrm{Wu}$ (2012), "Long-run covariance and its applications in cointegration regression", The Stata Journal, 12(3):515-542.

World Bank (2019), "Commodity Markets Outlook - Food Price Shocks: Channels and Implications", Washington, D.C.: World Bank, April 2019. 


\section{Appendix}

Table A1: Basic Statistics for Estimation of Consumption of Petroleum Products and Petroleum Tax Collection

State

Collection of State Taxes from Petroleum

Sales of Petroleum Products ('000

GSDP at Factor Cost* (at current prices, 2004-05 series) Products (Rs. Lakh) tonne)
(Rs Lakh)

\begin{tabular}{|c|c|c|c|c|c|c|c|c|c|c|c|c|c|}
\hline & Mean & Max & Min. & Std. Dev. & Mean & Max & Min. & Std. Dev. & Mean & Max & Min. & Std. Dev. & Obs. \\
\hline Andhra Pradesh & 714,683 & $1,569,500$ & 151,883 & 420,667 & 9,010 & 12,718 & 6,295 & 2,218 & $53,780,127$ & $121,000,000$ & $16,626,333$ & $33,431,478$ & 16 \\
\hline Bihar & 205,939 & 398,250 & 45,278 & 125,996 & 3,178 & 4,759 & 2,084 & 928 & $18,951,335$ & $41,719,578$ & $6,088,765$ & $11,985,204$ & 16 \\
\hline Chhattisgarh & 136,893 & 316,000 & 16,673 & 94,936 & 1,824 & 2,910 & 915 & 646 & $11,377,649$ & $23,608,222$ & $3,243,525$ & $6,876,047$ & 16 \\
\hline Goa & 39,439 & 64,600 & 14,999 & 13,763 & 900 & 1,083 & 651 & 145 & $2,869,693$ & $6,226,902$ & 785,869 & $1,707,485$ & 16 \\
\hline Gujarat & 503,515 & 968,617 & 237,604 & 213,747 & 13,720 & 18,980 & 7,307 & 4,574 & $49,607,350$ & $112,000,000$ & $13,288,747$ & $31,864,733$ & 16 \\
\hline Haryana & 281,753 & 642,700 & 63,685 & 178,835 & 7,080 & 10,774 & 3,726 & 2,818 & $24,204,456$ & $53,541,331$ & $6,706,908$ & $15,618,228$ & 16 \\
\hline Jharkhand & 113,089 & 286,000 & 19,460 & 80,351 & 1,978 & 2,921 & 1,107 & 555 & $11,021,957$ & $20,336,189$ & $4,083,187$ & $5,693,862$ & 16 \\
\hline Karnataka & 542,620 & $1,120,200$ & 125,237 & 324,298 & 7,375 & 11,459 & 4,876 & 2,115 & $38,810,627$ & $85,279,093$ & $12,044,640$ & $23,974,306$ & 16 \\
\hline Kerala & 337,511 & 667,800 & 103,372 & 174,677 & 4,532 & 5,724 & 3,418 & 801 & $25,386,315$ & $51,755,580$ & $8,428,719$ & $14,471,706$ & 16 \\
\hline Madhya Pradesh & 336,573 & 720,800 & 65,876 & 199,501 & 4,809 & 7,009 & 3,383 & 1,294 & $26,223,694$ & $61,071,205$ & $9,171,451$ & $16,567,114$ & 16 \\
\hline Maharashtra & $1,086,672$ & $1,962,700$ & 278,283 & 515,580 & 15,450 & 19,333 & 12,242 & 2,262 & $95,192,040$ & $202,000,000$ & $29,382,581$ & $55,991,612$ & 16 \\
\hline Odisha & 164,531 & 417,700 & 27,587 & 112,630 & 2,926 & 5,177 & 1,633 & 1,041 & $17,350,600$ & $34,861,253$ & $5,070,587$ & $9,975,373$ & 16 \\
\hline Punjab & 218,866 & 431,200 & 64,631 & 109,001 & 5,261 & 6,346 & 4,357 & 648 & $20,421,200$ & $39,189,625$ & $7,975,766$ & $10,629,400$ & 16 \\
\hline Rajasthan & 413,922 & 943,800 & 88,392 & 264,216 & 7,712 & 11,218 & 4,652 & 2,416 & $31,953,648$ & $70,214,628$ & $9,645,661$ & $20,680,243$ & 16 \\
\hline Tamil Nadu & 704,695 & $1,230,951$ & 188,827 & 371,086 & 10,734 & 13,499 & 8,140 & 2,015 & $53,103,659$ & $111,000,000$ & $16,109,356$ & $32,612,692$ & 16 \\
\hline Uttar Pradesh & 689,676 & $1,383,300$ & 167,481 & 432,302 & 11,308 & 15,930 & 8,914 & 2,110 & $56,460,238$ & $116,000,000$ & $19,943,634$ & $32,208,172$ & 16 \\
\hline West Bengal & 322,673 & 551,200 & 77,600 & 165,774 & 5,683 & 7,505 & 4,633 & 950 & $43,217,647$ & $87,605,695$ & $15,655,712$ & $23,997,251$ & 16 \\
\hline ALL & 400,768 & $1,962,700$ & 14,999 & 369,656 & 6,675 & 19,333 & 651 & 4,533 & $34,113,661$ & $202,000,000$ & 785,869 & $32,390,723$ & 272 \\
\hline
\end{tabular}

Source: Compiled from various issues of Indian Petroleum and Natural Gas Statistics 2009-10 to 2017-18 (MoP\&NG 2010 to 2018) 


\section{MORE IN THE SERIES}

- Nayudu, A. Sri Hari (2019). Tax Revenue Efficiency of Indian States: The case of Stamp Duty and Registration Fees, WP No. 278 (August).

- Chakraborty, L, (2019). Gender Budgeting as PFM in OECD Countries: Empirical Evidence from Sweden, WP No. 277 (August).

- Tandon, S., and Rao, R. K. (2019). Frontier analysis for State Excise in India,_WP No. 276 (August).
Sacchidananda Mukherjee, is Associate Professor, NIPFP

Email: sacchidananda.mukherjee@nipfp.org.in

National Institute of Public Finance and Policy,

$18 / 2$, Satsang Vihar Marg,

Special Institutional Area (Near JNU),

New Delhi 110067

Tel. No. 26569303, 26569780, 26569784

Fax: 91-11-26852548

www.nipfp.org.in 